\title{
Influence of wet extrudates from pumpkin seed proteins on drying, texture, and appearance of dry-cured hybrid sausages
}

\author{
Sandra Ebert ${ }^{1} \cdot$ Florence Jungblut $^{1} \cdot$ Kurt Herrmann $^{1} \cdot$ Barbara Maier $^{1} \cdot$ Nino Terjung $^{2} \cdot$ Monika Gibis $^{1} \cdot$ Jochen Weiss $^{1}$
}

Received: 18 November 2021 / Revised: 18 January 2022 / Accepted: 22 January 2022 / Published online: 6 March 2022

(c) The Author(s) 2022

\begin{abstract}
Hybrid meat products represent a promising, more sustainable alternative to all-meat formulations. However, differences among plant- and animal-based proteins may alter traditional handling and final product properties. In this study, pork meat was partially replaced with texturized pumpkin seed proteins at $12.5,25,37.5$, and 50\% to obtain dry-cured hybrid meat sausages and their ripening (acidification, drying) during 21 days and final product properties (texture, sensory) were characterized and compared to a control (all-meat formulation). The drying behavior and distribution of moisture and free water of hybrids with extrudate contents of 12.5 and $25 \%$ were comparable to the sample made with meat and no significant $(p>0.05)$ differences in proximate composition were found. In contrast, higher meat replacement levels resulted in distinct changes of compositional and textural attributes i.e. chewiness was decreasing by up to $70 \%$. Results suggested $25 \%$ of extrudates as an important threshold in manufacture of hybrid dry-cured sausages due to alterations in their ability to bind or release water. Results may be used to understand the influence of alternative texturized proteins in hybrid formulations and help product developers to understand related process and product relevant changes.
\end{abstract}

Keywords Hybrid meat products · Texturized plant proteins $\cdot$ Ripening $\cdot$ GDL $\cdot$ Drying

\section{Introduction}

The demand for meat has increased over the last decades, primarily due to an increase of the world population [International Food Policy Research Institute, [1]. Livestock production is one of the major drivers of greenhouse gas emissions and affects availability of land and water [2]. This together with health-related concerns with regards to consumption of meat and meat products [3] underlines the need to find alternative, consumer acceptable solutions to reduce meat consumption. One approach is to develop fully plant-based products wherein texturized plant proteins (extrudates) are used to imitate the characteristics texture and cooking behavior of meat [4]. Despite recent advances

Jochen Weiss

j.weiss@uni-hohenheim.de

1 Department of Food Material Science, Institute of Food Science and Biotechnology, University of Hohenheim, Garbenstrasse 21/25, 70599 Stuttgart, Germany

2 German Institute for Food Technology, Product Innovation, Professor-von-Klitzing-Straße 7, 49610 Quakenbrück, Germany in the field though, not all products were readily accepted by consumers [5] due to challenges to create an appealing texture, appearance, taste, and aroma. These limitations might be overcome if meat and texturized proteins were to be combined to create so-called hybrid meat products. There, the meat content is only partially reduced to still provide some of its unique functional and organoleptic properties. In this context, there are still a number of open questions on how texturized plant proteins behave in hybrid matrices leading to a lack of guidelines when it comes to formulations and processing operations. This is particularly true for dry-cured products, where the quality of raw materials combined with an appropriate process control is of importance to create a coherent, sliceable matrix, that has a good taste and is safe for consumption. For the latter, specific $\mathrm{pH}$ and moisture levels have to be achieved [6, 7]. In other words, differences in the proximate composition-especially moisture, protein, and fat content-and native $\mathrm{pH}$ of meat and plant extrudates might demand for adjustments in traditional formulations and manufacture.

This study investigates the influence of wet extrudates from unroasted pumpkin seed flour on the ripening behavior and textural and organoleptic properties of the dry-cured 
hybrid sausages. Four hybrid and a control (all-meat) drycured product were manufactured by chemical acidification with Glucono-delta-lactone (GDL) and subsequent drying. Special attention was paid to loss and distribution of water during ripening, and results were related to the textural properties of the final products. Findings were aimed at enhancing the understanding of functionality of texturized plant proteins in hybrid matrices to provide guidance on the development of manufacturing protocols that balance degree of acidification and drying to yield products with high consumer acceptance and long shelf life.

\section{Materials and methods}

\section{Materials}

Lean pork meat (75\% moisture, $20 \%$ protein, $5 \%$ fat, native pH 5.45) and pork backfat ( $8 \%$ water, $2 \%$ protein, $90 \%$ fat) were purchased from MEGA Fleisch GmbH (Stuttgart, Germany), standardized to $18 \mathrm{~mm}$ (fist-sized), and stored at $-18{ }^{\circ} \mathrm{C}$ until further use. Wet texturized pumpkin seed proteins $(60 \%$ moisture, $25 \%$ protein, $6 \%$ fat, $6 \%$ carbohydrates, native $\mathrm{pH}$ 6.70) were provided by Deutsches Institut für Lebensmitteltechnik (Quakenbrück, Germany). There, oilseed flour Pumpkin ${ }^{\circledR 60}$, Unroasted (60\% protein, $9 \%$ fat, $0.01 \%$ salt, $17 \%$ carbohydrates) from All Organic Treasures GmbH (Wiggensbach, Germany) was subjected to high moisture extrusion cooking in a double-screw extruder (ZSK 27MV, Coperion $\mathrm{GmbH}$, Stuttgart) at a water to powder ratio of 9 to 7. The inlet temperature of $40^{\circ} \mathrm{C}$ was increased stepwise to $145^{\circ} \mathrm{C}$. Protein plastification was done in the subsequently attached cooling die (FKD-750, DIL, Quakenbrück). The obtained extrudates were cut into stripes, packed airtight and stored at $-18{ }^{\circ} \mathrm{C}$ until further use. Curing salt (NPS) was obtained from ZENTRAG eG (Frankfurt, Germany). White pepper and ascorbic acid were purchased from MEGA Fleisch GmbH (Stuttgart, Germany). Glucono- $\delta$-lactone
(GDL), magnesium acetate (purity $\geq 99.5 \%$ p.a.), and sea sand were obtained from Carl Roth (Carl Roth GmbH \& Co KG, Karlsruhe, Germany). Ethylenediaminetetraacetic acid (EDTA) was purchased from Sigma-Aldrich (Sigma-Aldrich Chemie GmbH, Munich, Germany).

\section{Production of dry-cured (hybrid) sausages}

Part of the lean pork meat was thawed and minced to $3 \mathrm{~mm}$ with a meat grinder (model W 114, Maschinenfabrik Seydelmann KG, Stuttgart, Germany). Extrudates were thawed and chopped to particles of approx. $4 \mathrm{~mm}$. Frozen pork meat $\left(-18{ }^{\circ} \mathrm{C}, 18 \mathrm{~mm}\right)$, pork backfat $\left(-18{ }^{\circ} \mathrm{C}, 18 \mathrm{~mm}\right)$, white pepper, ascorbic acid, and GDL were chopped in a bowl chopper (model K 64 AC8 VAK, Maschinenfabrik Seydelmann KG, Aalen, Germany) at high speed to obtain the desired particle size. Following this, respective amounts of minced meat $\left(4{ }^{\circ} \mathrm{C}, 3 \mathrm{~mm}\right)$, chopped extrudates $\left(4{ }^{\circ} \mathrm{C}\right.$, $3 \mathrm{~mm}$ ), and nitrite curing salt were mixed in to obtain raw meat batters. The formulations are summarized in Table 1 . The meat content (frozen and chilled) was reduced from a total of $80 \%$ (Control) to 70, 60, 50, and $40 \%$ and replaced by $10,20,30$, and $40 \%$ of extrudates, respectively, which was representative for meat reduction levels of $12.5 \%$ (Hybrid 12.5), 25\% (Hybrid 25), 37.5\% (Hybrid 37.5), and $50 \%$ (Hybrid50). The amount of backfat was kept at $20 \%$. Nitrite curing salt was added at a traditional concentration of $2.6 \mathrm{~g} / \mathrm{kg}$ in all recipes for taste and safety reasons [6]. Following this, the batters were filled into sausage casings ( $d=50 \mathrm{~mm}$, Naturin Viscofan, Weinheim, Germany), hung onto drying racks and ripened for 21 days in a Unigar 1800 BE chamber (Ness \& Co. GmbH, Remshalden, Germany). Relative humidity $(\mathrm{RH})$ and temperature were kept constant at $94 \%$ and $25{ }^{\circ} \mathrm{C}$ during the first $24 \mathrm{~h}$. Sausages were then cold smoked $\left(23^{\circ} \mathrm{C}\right.$, RH $\left.75 \%\right)$ twice for $10 \mathrm{~min}$. Afterwards, RH was stepwise decreased to $85 \%$ (5 days), $80 \%$ (5 days), $75 \%$ (5 days), $72 \%$ (5 days) at $18{ }^{\circ} \mathrm{C}$ to ensure homogeneous drying. Ripening parameters were chosen according to
Table 1 Formulation of the control formulation and drycured hybrid sausages

\begin{tabular}{llllll}
\hline & Control & Hybrid 12.5 & Hybrid 25 & Hybrid 37.5 & Hybrid 50 \\
\hline Ingredient $(\%)$ & & & & & \\
Pork backfat $\left(18 \mathrm{~mm},-18^{\circ} \mathrm{C}\right)$ & 20 & 20 & 20 & 20 & 20 \\
Lean pork meat $\left(18 \mathrm{~mm},-18^{\circ} \mathrm{C}\right)$ & 45 & 40 & 35 & 30 & 25 \\
Lean pork meat $\left(3 \mathrm{~mm}, 4^{\circ} \mathrm{C}\right)$ & 35 & 30 & 25 & 20 & 15 \\
Pumpkin Texturate $\left(3 \mathrm{~mm}, 4^{\circ} \mathrm{C}\right)$ & 0 & 10 & 20 & 30 & 40 \\
Additives $(\mathrm{g} / \mathrm{kg})$ & & & & & \\
Nitrite curing salt & 2.6 & 2.6 & 2.6 & 2.6 & 2.6 \\
Pepper, white & 3.0 & 3.0 & 3.0 & 3.0 & 3.0 \\
Ascorbic acid & 0.5 & 0.5 & 0.5 & 0.5 & 0.5 \\
Corrected GDL & 7.3 & 9.8 & 12.3 & 14.8 & 17.4 \\
\hline
\end{tabular}

${ }^{\mathrm{a}}$ Calculated according to a mathematical model from preliminary experiments (unpublished results) 
preliminary experiments (not shown), that were adjusted from previous studies $[8,9]$. All samples were prepared from the same raw materials with at least 15 sausages per formulation.

\section{Ripening behavior}

\section{Acidification}

The $\mathrm{pH}$ of sausages (control formulation and dry-cured hybrids) was measured during $120 \mathrm{~h}$ of ripening at select timepoints $(0,0.5,1.5,2.5,4.5,5.5,24,72,120 \mathrm{~h})$ with a $\mathrm{pH}$-meter (Microprocessor pH Meter 537 with BlueLine21 electrode, WTW GmbH, Weilheim, Germany). The timedependent $\mathrm{pH}$-value was obtained as the average from all individual sausages. Each sausage was analyzed at least three-times.

\section{Weight loss and drying rates}

The weight of samples was determined daily during 21 days of ripening with a scale (U4100, Sartorius Lab Instruments GmbH \& Co. KG, Göttingen, Germany). The relative weight loss related to the sausage weight and the absolute weight loss related to the initial moisture content were calculated according to Eqs. (1) and (2). The respective drying rates were calculated according to Eqs. (3) and (4).

Relative weight $\operatorname{loss}_{\text {dayi }} \operatorname{RWL}(\%)=100-\left(\frac{m_{\text {day } i}}{m_{0}}\right) \cdot 100$

Absolute weight $\operatorname{loss}_{\text {dayi }}$ AWL (\%)

$$
=100-\left(\frac{\left(\frac{\mathrm{MC}_{\mathrm{o}}}{100} * m_{\mathrm{o}}\right)-\left(m_{\mathrm{o}}-m_{\mathrm{day} i}\right)}{\left(\frac{\mathrm{MC}_{\mathrm{o}}}{100} * m_{\mathrm{o}}\right)} \cdot 100\right)
$$

Drying rate $\operatorname{RWL}(\% / \mathrm{h})=\frac{\mathrm{RWL}_{i}}{\Delta d_{i}}$

Drying rate $\operatorname{AWL}(\% / \mathrm{h})=\frac{\mathrm{AWL}_{i}}{\Delta d_{i}}$,

where $m_{0}$ is the sausage weight at day $0(\mathrm{~g}), m_{\text {day } i}$ is the Sausage weight at day $I(\mathrm{~g}), \mathrm{MC}_{0}$ is the moisture content of raw (hybrid) meat batter at day $0(\%)$, and $\Delta d_{i}$ is the elapsed drying time (h). The time-dependent RWL and AWL and the respective drying rates were obtained as the average from the data obtained from the individual sausages. Each sausage was analyzed at least three-times.

\section{Chemical analysis}

\section{Sample preparation}

Raw (hybrid) meat batters (day 0) and dried (hybrid) sausages (day 21) were peeled, cut into smaller pieces, chopped with a blender (type 4 171, Braun GmbH, Kronberg im Taunus, Germany) until homogeneous, packed airtight, and stored at $4{ }^{\circ} \mathrm{C}$ until analysis. Furthermore, (hybrid) sausages at day $3,5,8,14,21$ were subdivided into four different layers using a slicing machine (model VS 8A, Bizerba SE \& Co. KG, Bailingen, Germany). Layer I represented the outer $3 \mathrm{~mm}$ of sausage, Layer II and Layer III were cut to a thickness of $6 \mathrm{~mm}$ each (3-9 $\mathrm{mm}$ and $9-15 \mathrm{~mm}$ ). Layer IV represented the remaining Core. Individual layers were chopped and stored as outlined before. Each sausage was analyzed at least in duplicates unless otherwise stated.

\section{Moisture content}

The dry matter and moisture content of raw (hybrid) meat batters (day 0), dried (hybrid) sausages (day 21), and their layers (day $3,5,8,14,21$ ) were determined gravimetrically with the sea sand method (AS § 64 L 06.00-3, BVL [10]). Approximately $10 \mathrm{~g}$ of sample were used.

\section{Water activity $\left(a_{\mathrm{w}}\right.$-value $)$}

Water activity ( $\mathrm{a}_{\mathrm{w}}$-value) of raw (hybrid) meat batters (day 0 ), dried (hybrid) sausages (day 21), and their layers (day $3,5,8,14,21$ ) was determined with a water activity meter (HygroPalm AW1, rotroic AG, Bassersdorf, Switzerland) at room temperature.

\section{Total ash content}

The total ash content of raw (hybrid) meat batters (day 0) and dried (hybrid) sausages (day 21) was obtained after preincineration, followed by complete combustion at $600{ }^{\circ} \mathrm{C}$ (AS § 64 L 06.00-4, BVL [10]). Approximately $5 \mathrm{~g}$ of sample were used for analysis.

\section{Total nitrogen and crude protein content}

The total nitrogen content of raw (hybrid) meat batters (day 0 ) and dried (hybrid) sausages (day 21) was determined according to Dumas (AS § 64 L 06.00-20, BVL [10]). EDTA was used as a standard for calibration. Crude protein content was derived by a multiplication with a nitrogen-to-protein conversion factor of 6.25 . 


\section{Total fat content}

Total fat was determined by applying the method of WeibullStoldt (AS $\S 64$ L 07.00-6, BVL [10] followed by a lowboiling Soxhlet extraction with petroleum ether. Pre-dried sample residues from moisture determination (see "Moisture content") were used for analysis.

\section{Appearance and color}

Dry-cured (hybrid) sausages (21 days) were sliced to $17 \mathrm{~mm}$ thickness and scanned with a scanner (model V100 Photo, Seiko Epson Corporation, Suwa, Japan). The interior color was analyzed with a Chroma-Meter CR-200 (Minolta, Osaka, Japan) using the CIE $L * a * b$ color space and a standard observer at a $2^{\circ}$ angle and $\mathrm{D}_{65}$ as illumination. Calibration was done with a white standard $(Y=86.9, x=0.3183$, $\mathrm{y}=0.3352)$. The color distance $\Delta E$ of dry-cured hybrid sausages from the Control was calculated according to Eq. (5). Each sausage was analyzed at least in triplicates.

$$
\Delta E=\sqrt{\left(L_{\mathrm{C}}-L_{\mathrm{H}}\right)^{2}+\left(a_{\mathrm{C}}-a_{\mathrm{H}}\right)^{2}+\left(b_{\mathrm{C}}-b_{\mathrm{H}}\right)^{2}},
$$

where $L, a$ and $b$ were the lightness, red-green balance and yellow-blue balance of the control (subscript C) and hybrid (subscript $\mathrm{H}$ ) sausage, respectively.

\section{Texture profile analysis}

Textural parameters (hardness, cohesiveness, springiness) of (hybrid) sausages were analyzed with a cyclic double compression test (Instron type 3365, Instron, Darmstadt, Germany) at a $50 \%$ compression. The chewiness was obtained from Eq. (6). Each sausage sample was analyzed at least 10-times.

$$
\begin{aligned}
\text { Chewiness }\left(\mathrm{N}^{*} \mathrm{~mm}\right)= & \text { Cohesiveness }(-) \\
& \cdot \text { Hardness }(\mathrm{N}) \cdot \text { Springiness }(\mathrm{mm})
\end{aligned}
$$

\section{Statistical analysis}

Statistically significant differences among samples were tested by a one-way analysis of variance with a Duncan posthoc-test ( $\alpha$-level of 0.05) using SPSS statistics V23 (IBM Corp., Armonk, NY, USA) after checking the assumption of normality (Shapiro-Wilk-test, $p$-value to reject $\leq 0.05$ ) and equal variance $(p \leq 0.05)$.

\section{Results and discussion}

The ripening of dry-cured sausages is important for key product characteristics such as microbial stability and texture [6]. It is generally divided into two steps (1) acidification of raw meat batters at high relative humidity and (2) drying at decreasing relative humidity until the desired weight loss/ moisture level is reached. For this reason, results pertaining to the chemical acidification with GDL (0-120 h) of drycured hybrid sausages and a control (all-meat) formulation are discussed first, followed by an evaluation of the drying behavior and moisture distribution during 21 days of ripening. Results were then discussed in relation to the textural properties and appearance of ripened products to gain first insights into the organoleptic aspects of using extrudates in dry-cured formulations. Wet texturized pumpkin seed proteins (extrudates) were used at meat replacement levels of $12.5 \%, 25 \%, 37.5 \%$, and $50 \%$ (Table 1), representative of samples labelled Hybrid 12.5, Hybrid 25, Hybrid 37.5, and Hybrid 50.

\section{Acidification behavior}

Start and thus mixing $\mathrm{pH}$-values of raw (hybrid) meat batters were slightly, but not significantly $(p>0.05)$ different with pH 5.55 \pm 0.07 (Control), pH $5.75 \pm 0.01$ (Hybrid 25), pH $5.77 \pm 0.01$ (Hybrid 37.5), pH $5.81 \pm 0.33$ (Hybrid 50), and $\mathrm{pH} 5.85 \pm 0.05$ (Hybrid 12.5) (Table 2). The timedependence of $\mathrm{pH}$ of all samples was similar with a steep $\mathrm{pH}$-drop, followed by a further slow and less pronounced acidification. Small differences in initial mixing $\mathrm{pH}$ were compensated by a faster acidification of hybrid samples (0.62 to $0.68 \mathrm{pH}$-units after $5.5 \mathrm{~h}$ ) compared to the control $(0.50 \mathrm{pH}$-units after $5.5 \mathrm{~h})$. After $120 \mathrm{~h}$, final values of pH 5.02 \pm 0.02 (Control), pH $5.01 \pm 0.01$ (Hybrid 12.5), $\mathrm{pH} 4.96 \pm 0.01$ (Hybrid 25), pH 5.02 \pm 0.02 (Hybrid 37.5), $\mathrm{pH} 4.96 \pm 0.01$ (Hybrid 50) were reached.

When it comes to dry-cured sausages, a final $\mathrm{pH}$ of 5.0 is considered to be a good target value to achieve safety against food pathogens such as Salmonella spp. or Lysteria monocytogenes [7]. Moreover this ensures a sufficient denaturation of myofibrillar meat proteins as prerequisite for coherent gel formation in the final product [11]. It can be achieved by the addition of starter cultures and sugar or via a chemical acidifier such as GDL. The latter has recently gained popularity in particular in mixed biopolymer systems [12-14], since its application quantity can be adjusted according to the formulation and the desired $\mathrm{pH}$-drop. There, intensity and speed of acidification can be modulated since first-order reaction rates of GDL-hydrolysis depend on the matrix $\mathrm{pH}$ and/or acidifier amount $[15,16]$. In this study, GDL-concentrations were adjusted according to the extrudate concentration to achieve 
Table 2 Time-dependent $\mathrm{pH}$-course of the control formulation and dry-cured hybrid sausages during $120 \mathrm{~h}$ acidified with GDL

\begin{tabular}{llllll}
\hline Time (h) & Control & Hybrid 12.5 & Hybrid 25 & Hybrid 37.5 & Hybrid 50 \\
\hline 0 & $5.55 \pm 0.08^{\mathrm{a}, \mathrm{A}}$ & $5.85 \pm 0.02^{\mathrm{a}, \mathrm{A}}$ & $5.75 \pm 0.01^{\mathrm{a}, \mathrm{A}}$ & $5.77 \pm 0.07^{\mathrm{a}, \mathrm{A}}$ & $5.81 \pm 0.33^{\mathrm{a}, \mathrm{A}}$ \\
0.5 & $5.52 \pm 0.01^{\mathrm{b}, \mathrm{B}}$ & $5.49 \pm 0.04^{\mathrm{b}, \mathrm{B}}$ & $5.64 \pm 0.01^{\mathrm{ab}, \mathrm{B}}$ & $5.73 \pm 0.06^{\mathrm{a}, \mathrm{A}}$ & $5.79 \pm 0.12^{\mathrm{a}, \mathrm{A}}$ \\
1.5 & $5.46 \pm 0.02^{\mathrm{a}, \mathrm{C}}$ & $5.39 \pm 0.04^{\mathrm{ab}, \mathrm{C}}$ & $5.35 \pm 0.01^{\mathrm{b}, \mathrm{C}}$ & $5.37 \pm 0.05^{\mathrm{ab}, \mathrm{B}}$ & $5.42 \pm 0.05^{\mathrm{ab}, \mathrm{B}}$ \\
2.5 & $5.15 \pm 0.01^{\mathrm{b}, \mathrm{D}}$ & $5.20 \pm 0.01^{\mathrm{a}, \mathrm{D}}$ & $5.19 \pm 0.01^{\mathrm{a}, \mathrm{D}}$ & $5.19 \pm 0.01^{\mathrm{a}, \mathrm{C}}$ & $5.15 \pm 0.02^{\mathrm{b}, \mathrm{BC}}$ \\
4.5 & $5.10 \pm 0.01^{\mathrm{c}, \mathrm{DE}}$ & $5.15 \pm 0.01^{\mathrm{ab}, \mathrm{DE}}$ & $5.19 \pm 0.01^{\mathrm{a}, \mathrm{D}}$ & $5.12 \pm 0.03^{\mathrm{bc}, \mathrm{CD}}$ & $5.14 \pm 0.02^{\mathrm{abc}, \mathrm{BC}}$ \\
5.5 & $5.10 \pm 0.01^{\mathrm{a}, \mathrm{DE}}$ & $5.13 \pm 0.04^{\mathrm{a}, \mathrm{DE}}$ & $5.13 \pm 0.01^{\mathrm{a}, \mathrm{DE}}$ & $5.12 \pm 0.04^{\mathrm{a}, \mathrm{CD}}$ & $5.14 \pm 0.01^{\mathrm{a}, \mathrm{BC}}$ \\
24 & $5.07 \pm 0.01^{\mathrm{ab}, \mathrm{EF}}$ & $5.09 \pm 0.02^{\mathrm{b}, \mathrm{EF}}$ & $5.09 \pm 0.01^{\mathrm{b}, \mathrm{E}}$ & $5.08 \pm 0.01^{\mathrm{b}, \mathrm{DE}}$ & $5.03 \pm 0.03^{\mathrm{a}, \mathrm{C}}$ \\
72 & $5.04 \pm 0.03^{\mathrm{a}, \mathrm{FG}}$ & $5.04 \pm 0.04^{\mathrm{a}, \mathrm{FG}}$ & $5.07 \pm 0.02^{\mathrm{a}, \mathrm{E}}$ & $5.09 \pm 0.03^{\mathrm{a}, \mathrm{DE}}$ & $5.08 \pm 0.01^{\mathrm{a}, \mathrm{C}}$ \\
120 & $5.02 \pm 0.02^{\mathrm{a}, \mathrm{G}}$ & $5.01 \pm 0.01^{\mathrm{a}, \mathrm{G}}$ & $4.96 \pm 0.01^{\mathrm{b}, \mathrm{F}}$ & $5.02 \pm 0.02^{\mathrm{a}, \mathrm{E}}$ & $4.94 \pm 0.01^{\mathrm{b}, \mathrm{C}}$ \\
\hline
\end{tabular}

Different lower-case letters indicate significant difference $(p \leq 0.05)$ among formulations at the same timepoint;

Different upper-case letters indicate significant difference $(p \leq 0.05)$ among timepoints from one formulation a final $\mathrm{pH}$ of 5.0. This resulted in faster and longer lasting acidification of Hybrids compared to the Control and initial differences in mixing $\mathrm{pH}$ disappeared after $5.5 \mathrm{~h}$. Following this, further $\mathrm{pH}$-declines in hybrids resulted in a final $\mathrm{pH}$ of $\mathrm{pH} 5.00 \pm 0.06$. As such, the overall time-dependent $\mathrm{pH}-$ development was typical for a GDL-induced acidification $[6,12,17,18]$, indicating that hybrids can be manufactured with a targeted $\mathrm{pH}$-value in mind using GDL. This may be of interest for product developers since $\mathrm{pH}$-variations of alternative proteins in hybrid formulations as shown by other authors [19-23] may be overcome.

\section{Drying behavior and proximate composition}

The drying behavior was analyzed by monitoring the weight of dry-cured (hybrid) sausages during 21 days/504 h of ripening ( $24 \mathrm{~h}$ of acidification at higher humidity, 20 days/480 h of drying at deceasing humidity). The relative weight loss RWL (Fig. 1A) related to the original sausage weight $m_{0}$ and the absolute weight loss AWL (Fig. 1B) based on the original moisture weight $\mathrm{MC}_{\mathrm{o}}$ were calculated according to Eqs. (1) and (2). Respective relative and absolute drying rates were derived from Eqs. (3) and (4). The moisture weight for calculations of the absolute weight loss (Fig. 1B) was obtained from Table 3 where the protein, fat, ash, and the free water content expressed via the water activity value ( $a_{\mathrm{w}}$-value) of raw (hybrid) meat batters and final products (21 days) are additionally shown. Both the relative (Fig. 1A) and the absolute (Fig. 1B) weight loss curves followed the same course with an initial rapid increase occurring in between day one (24 h) and six (144 h), followed by a more gradual weight loss indicating a deceleration of drying. Correspondingly, drying rates increased during the first $96 \mathrm{~h}$, remained high for another $48 \mathrm{~h}$ and decreased until the end of the ripening time. For example, the Control formulation had a drying rate of $0.091 \% / \mathrm{h}$ after
$24 \mathrm{~h}, 0.144 \% / \mathrm{h}$ after $96 \mathrm{~h}, 0.133 \% / \mathrm{h}$ after $144 \mathrm{~h}$ and finally $0.070 \% / \mathrm{h}$ after $504 \mathrm{~h}$ (Fig. 1A). Furthermore, there were differences in both weight loss and rate between the different formulations (Fig. 1A, Fig. 1B). First, higher meat replacement levels resulted in lower relative weight losses (Fig. 1A) at any given time i.e. at day six (144 h) the weight losses were $19.2 \pm 0.5 \%$ (Control) $>19.2 \pm 0.2 \%$ (Hybrid $12.5)>18.7 \pm 0.2($ Hybrid 25$)>17.7 \pm 0.5 \%($ Hybrid 37.5$)$ $>15.6 \pm 0.3 \%$ (Hybrid 50). Statistically, Hybrid 12.5 and Hybrid 25 sausages were not significantly different $(p \leq 0.05)$ to the Control from day 15 , and the final relative weight loss of these three formulations was comparable (around 35\%). In contrast, Hybrid 37.5 and Hybrid 50 incurred lower relative weight losses of $32.5 \pm 0.2 \%$ and $29.2 \pm 0.2 \%$, respectively. If the absolute weight loss was considered (Fig. 1B), Hybrid 25 sausages had the largest values, followed by Hybrid 12.5, Hybrid 37.5, the Control, and the Hybrid 50, e.g. samples had lost $41.8 \pm 0.5 \%, 41.5 \pm 0.5 \%, 40.9 \pm 0.4 \%$, $40.6 \pm 1.1 \%$, and $36.8 \pm 0.3 \%$ at day $10(240 \mathrm{~h})$, respectively. There, the Control and hybrids having extrudate contents of 12.5 to $37.5 \%$ were comparable, and distinct differences were found only for the sample with $50 \%$ extrudates (Hybrid 50). Replacement of pork meat with extrudates from pumpkin seed proteins resulted in slight elevations in protein and decreases in fat content, but this did not translate into significant differences $(p>0.05)$ in dry-cured (hybrid) sausages (Table 3 ). However, small variations in the initial moisture content developed to significant $(p \leq 0.05)$ ones in dried end products when meat replacement levels exceeded $12.5 \%$, and $a_{\mathrm{w}}$ values ranged from 0.890 (Hybrid 37.5) to 0.909 (Control, Hybrid 25).

Typical drying curves of dry-cured sausages consist of three phases: (1) an induction period (short time, increase of the surface to the wet bulb temperature), (2) a constant rate period (constant drying rate, removal of water from the wet sausage surface), and (3) a falling rate period (removal of 

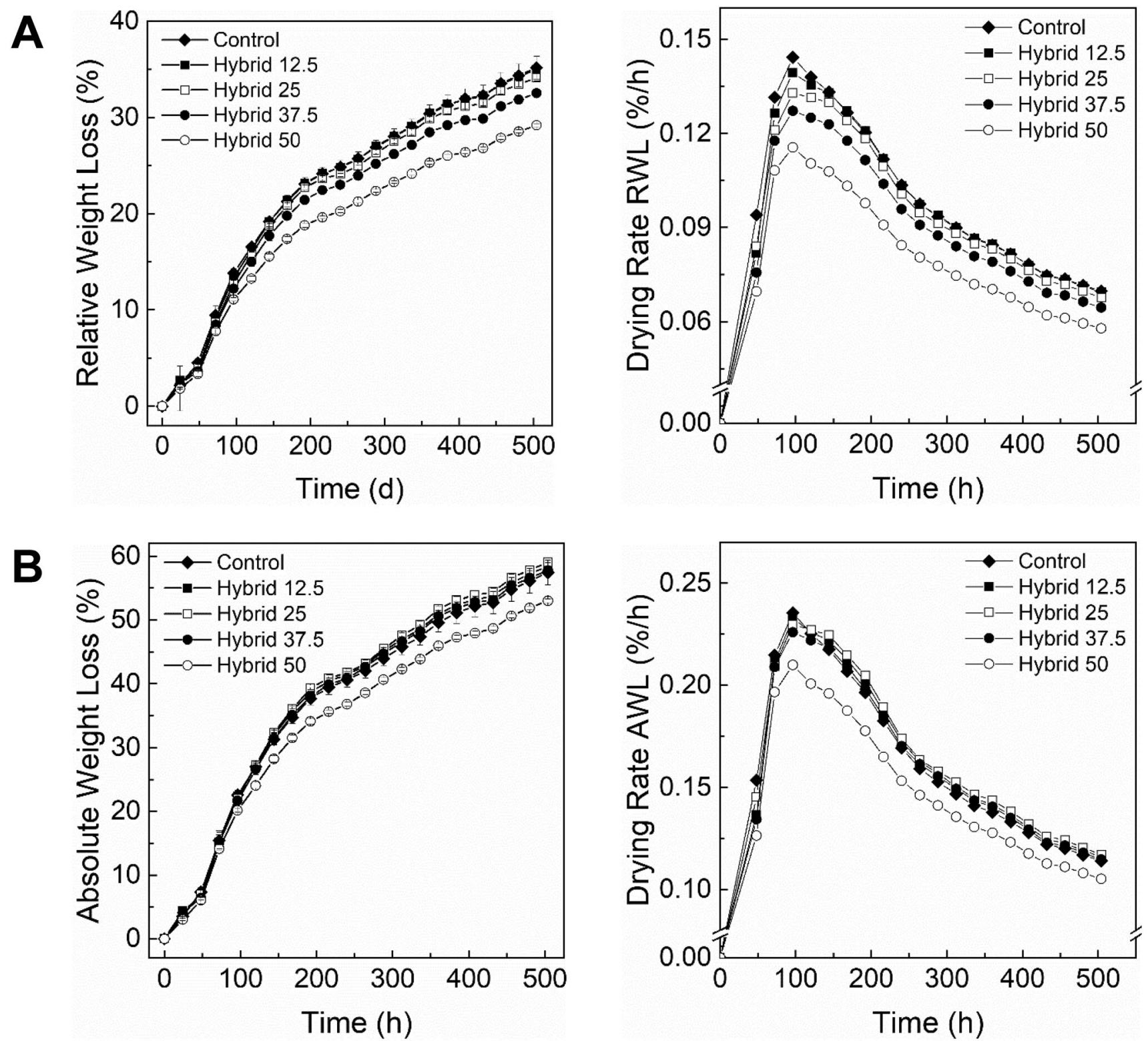

Fig. 1 Relative weight loss and drying rate related to the sausage weight $\left(m_{0}\right)(\mathbf{A})$ and absolute weight loss and drying rate related to the original moisture content $\left(\mathrm{MC}_{0}\right)(\mathbf{B})$ of the control formulation

internal moisture by diffusion) [24]. In this study, moisture decreased slightly within the first $48 \mathrm{~h}$ with average drying rates among all samples (Fig. 1B) of $0.149 \pm 0.020 \% / \mathrm{h}$ (induction period), followed by a linear $96 \mathrm{~h}$ decline in absolute weight loss (not shown) at an average drying rate of $0.218 \pm 0.008 \% / \mathrm{h}$, indicating that the drying had entered the constant rate period. The falling rate period began after $168 \mathrm{~h}$ (7 days) where average drying rates decreased by $45 \%$. Along with the $\mathrm{pH}$ of around 5.0 (Table 2), a final moisture content between 30 and $40 \%$, and a water activity of $\mathrm{a}_{\mathrm{w}}<0.91$ represent common target values in dry and semidry sausages $[7,25,26]$. Considering this, all formulations and dry-cured hybrid sausages during $21 \mathrm{~d}$ of ripening (RH $94 \%$ ( 1 day), $85 \%$ ( 5 days), $80 \%$ ( 5 days), $75 \%$ (5 days), $72 \%$ ( 5 days))

were sufficiently ripened to achieve microbial stability and shelf life (Table 3). Small differences in proximate composition could be related to differences in their drying behavior (Fig. 1A, B), which depends on some internal and external parameters, such as the used raw materials and/or additives, the sausage diameter and temperature, the relative humidity, and the air velocity. For example, Walz et al. [27] dried microbially fermented small caliber $(20-22 \mathrm{~mm})$ pork meat sausages with different casing materials to a final weight loss of $41.5 \%$ in as little as $101 \mathrm{~h}$ (natural casing) to as long as $134 \mathrm{~h}$ (alginate or collagen casing). This resulted in 20-21\% of moisture and 5.5-7.4\% of ash. In contrast, Yim et al. [28] 
Table 3 Proximate composition and $a_{\mathrm{w}}$-value of the control formulation and dry-cured hybrid sausages at day 0 and day 21

\begin{tabular}{|c|c|c|c|c|c|c|}
\hline & Time (days) & Control & Hybrid 12.5 & Hybrid 25 & Hybrid 37.5 & Hybrid 50 \\
\hline \multirow[t]{2}{*}{ Moisture (\%) } & 0 & $61.2 \pm 0.7^{\mathrm{a}}$ & $59.9 \pm 4.7^{\mathrm{ab}}$ & $58.0 \pm 0.2^{\mathrm{ab}}$ & $56.3 \pm 0.3^{\mathrm{ab}}$ & $55.1 \pm 0.1^{\mathrm{b}}$ \\
\hline & 21 & $44.2 \pm 0.7^{\mathrm{a}}$ & $43.2 \pm 0.9^{\mathrm{a}}$ & $40.9 \pm 0.5^{\mathrm{b}}$ & $34.8 \pm 0.9^{c}$ & $34.3 \pm 0.1^{\mathrm{c}}$ \\
\hline \multirow[t]{2}{*}{ Crude protein ${ }^{\mathrm{a}}(\%)$} & 0 & $17.5 \pm 0.3^{\mathrm{a}}$ & $18.3 \pm 0.5^{\mathrm{a}}$ & $18.0 \pm 1.6^{\mathrm{a}}$ & $18.3 \pm 1.3^{\mathrm{a}}$ & $19.2 \pm 0.7^{\mathrm{a}}$ \\
\hline & 21 & $25.2 \pm 2.1^{\mathrm{a}}$ & $27.0 \pm 0.9^{\mathrm{a}}$ & $26.3 \pm 1.8^{\mathrm{a}}$ & $26.3 \pm 1.1^{\mathrm{a}}$ & $27.8 \pm 1.7^{\mathrm{a}}$ \\
\hline \multirow[t]{2}{*}{ Specific protein $(\%)^{\mathrm{b}}$} & 0 & $17.5 \pm 0.3^{\mathrm{a}}$ & $18.0 \pm 0.4^{\mathrm{a}}$ & $17.5 \pm 1.6^{\mathrm{a}}$ & $17.5 \pm 1.2^{\mathrm{a}}$ & $18.0 \pm 0.7^{\mathrm{a}}$ \\
\hline & 21 & $25.2 \pm 2.1^{\mathrm{a}}$ & $26.6 \pm 0.8^{\mathrm{a}}$ & $25.5 \pm 1.8^{\mathrm{a}}$ & $25.2 \pm 1.0^{\mathrm{a}}$ & $26.1 \pm 1.6^{\mathrm{a}}$ \\
\hline \multirow[t]{2}{*}{ Total fat (\%) } & 0 & $18.1 \pm 0.3^{\mathrm{a}}$ & $17.4 \pm 2.6^{\mathrm{a}}$ & $18.1 \pm 0.3^{\mathrm{a}}$ & $17.3 \pm 0.4^{\mathrm{a}}$ & $16.9 \pm 0.4^{\mathrm{a}}$ \\
\hline & 21 & $25.7 \pm 0.8^{\mathrm{a}}$ & $25.2 \pm 1.1^{\mathrm{a}}$ & $26.2 \pm 0.6^{\mathrm{a}}$ & $26.9 \pm 1.1^{\mathrm{a}}$ & $26.3 \pm 0.5^{\mathrm{a}}$ \\
\hline \multirow[t]{2}{*}{ Total ash $(\%)$} & 0 & $3.49 \pm 0.03^{\mathrm{ab}}$ & $3.62 \pm 0.07^{\mathrm{a}}$ & $4.05 \pm 0.01^{\mathrm{a}}$ & $4.17 \pm 0.01^{\mathrm{a}}$ & $2.87 \pm 0.61^{\mathrm{b}}$ \\
\hline & 21 & $4.92 \pm 0.03^{\mathrm{c}}$ & $5.05 \pm 0.07^{\mathrm{c}}$ & $5.28 \pm 0.11^{\mathrm{b}}$ & $6.28 \pm 0.12^{\mathrm{a}}$ & $6.06 \pm 0.09^{\mathrm{a}}$ \\
\hline \multirow[t]{2}{*}{$a_{\mathrm{w}}(-)$} & 0 & $0.962 \pm 0.004^{\mathrm{a}}$ & $0.957 \pm 0.012^{\mathrm{a}}$ & $0.953 \pm 0.006^{\mathrm{a}}$ & $0.961 \pm 0.011^{\mathrm{a}}$ & $0.967 \pm 0.025^{\mathrm{a}}$ \\
\hline & 21 & $0.909 \pm 0.006^{\mathrm{a}}$ & $0.908 \pm 0.014^{\mathrm{ab}}$ & $0.909 \pm 0.001^{\mathrm{a}}$ & $0.890 \pm 0.001^{b}$ & $0.898 \pm 0.004^{\mathrm{ab}}$ \\
\hline
\end{tabular}

Different lower-case letters indicate significant difference $(p \leq 0.05)$ among formulations at the same timepoint

${ }^{a}$ Nitrogen to protein conversion factor $=6.25[50]$

${ }^{\mathrm{b}}$ Calculation based on extrudate share and nitrogen-to-protein conversion factor for meat $=6.25[50]$ and pumpkin seeds $=5.50[51]$

combined starter cultures and GDL and beef and pork meat to ferment sausages at $55 \mathrm{~mm}$ diameter having a comparable proximate composition as the Control (Table 3). This yielded samples with final moisture, fat, protein, and ash levels ranging between 29 and 34\%, 31 and 34\%, 28 and $31 \%$, and 5.1 and $5.4 \%$ after 25 days of ripening. At the end, the proximate composition of products is related to the targeted characteristics of the sausage variety e.g. fast vs. medium vs. slow fermented, dry vs. semi-dry or small vs. big diameter sausages [6]. These characteristics impact the drying behavior as fast drying of small calibers generally results in a short, steep drying regime, followed by a long gradual one, while slow drying and/or big diameters prolongs the first and shortens the latter [27-29]. In this study, relative (Fig. 1A) and absolute weight loss (Fig. 1B) of hybrid sausages and the control formulation were representative for slow drying curves due to their large diameters $(50 \mathrm{~mm})$, slowly decreasing relative humidity of the drying air, and low total drying rates after 21 days of ripening, more precisely $0.105 \% / \mathrm{h}$ (Hybrid 50), 0.114\%/h (Control), $0.115 \% / \mathrm{h}$ (Hybrid 37.5), 0.116\%/h (Hybrid 12.5), and $0.117 \% / \mathrm{h}$ (Hybrid 25) (Fig. 1B). This also shows that lower moisture contents (Table 3 ) may correlate with slower relative weight loss and drying rates (Fig. 1A) of Hybrid 37.5 and Hybrid 50 in comparison to the Control, since dry(er) products have a lower moisture migration than wet ones [30].

Considering literature data on hybrid meat products, a lot of research has been done on the effect of texturized proteins as meat replacers in boiled meat products [31-35]. The search for suitable texturized fat alternatives in raw ferments has also led to recent investigations [8] and the effect of meat replacement upon microbial fermentation was assessed [21]. Despite differences in the assessed type of meat product, extrudates used (dry vs. wet texturized plant proteins), and acidification method applied (starter culture vs. GDL) some results may be of relevance for those obtained here. For example, Zepeda Bastida et al. [21] assessed the effect of textured soy proteins in raw rabbit meat sausages at replacement levels of 10-40\%. Ripening was performed for 14 days which resulted in a final $a_{\mathrm{w}}$ between 0.625 (Control formulation) and 0.945 (40\% hybrid). There, authors concluded that increasing shares of extrudates resulted in an increased water holding capacity. Omwamba et al. [35] found a similar effect upon beef meat replacement of samosa stuffing using texturized soy proteins, with moisture levels of the final products increasing along with decreasing protein and fat contents. While both studies used dry texturized instead of wet texturized proteins, differences in the water holding capacity of extrudates compared to meat should be considered in particular for Hybrid 37.5 and Hybrid 50 sausages. As extrudates from pumpkin seed flours have a high dietary fiber content (around 5\% according to the manufacturers specification), results may also be related to those obtained from raw ferments with plant-based fibers. For example, the addition of 1 or $2 \%$ of tiger nut fiber resulted in higher moisture, comparable protein and fat contents, and lower water activity and weight loss of end products [36]. Similarly, the addition of a citrus fiber to chorizo formulations decreased the $a_{\mathrm{w}}$ and moisture content in Longaniza de Pascua [37], and 2 to $4 \%$ of orange fiber decreased the cooking loss of Sucuk [38]. In our study, meat replacement levels of $37.5 \%$ and $50 \%$ could be related to a dietary fiber content of around $1.88 \%$ and $2.50 \%$ (according to the manufacturers specifications) which may be one reason for the lower weight loss of the Hybrid 37.5 in comparison to Hybrid 25 and 12.5 sausages and the lagged drying behavior of Hybrid 50 . 
This could also explain the somewhat lower water activity of dried hybrids (Table 3) with water being sorptively bound to the matrix. Moreover, swelling of fibers may have decreased the pore size of the matrix and thereby reduced the tendency of water to be released through the extrudates' cavities [39]. However, it is important to say that the degree of acidification and thus the final $\mathrm{pH}$-value also influences the drying behavior of sausages since the water holding capacity of meat is negatively correlated with the $\mathrm{pH}$-value. As a result, literature data on lower or higher weight loss of hybrid meats may also be related to pH-effects of the used plant-based meat replacers $[21,35]$ or additives $[36,37,40]$.

All in all, meat replacements of up to $25 \%$ resulted in comparable or lower moisture levels after 21 days of ripening, while higher meat replacement levels showed the opposite trend. This might be indicative of a threshold concentration of extrudates in dry-cured hybrid meats above which negative effects become dominant hinting at a complex interplay of compositional elements such as dietary fiber and initial moisture levels on the drying behavior of drycured (hybrid) meat matrices.

\section{Distribution of moisture and free water}

A more in-depth knowledge of the water distribution in drycured sausages during ripening can provide further insights into the drying behavior and quality development in products. Therefore, dry-cured (hybrid) sausages were sectioned into four layers, namely Layer I (outer $3 \mathrm{~mm}$ ), Layer II (following $6 \mathrm{~mm}$ ), Layer III (following $6 \mathrm{~mm}$ ), and a Core Layer (remaining layer), and analyzed as to their moisture (Fig. 2, "Appendix I") and $a_{\mathrm{w}}$ values (Fig. 3, "Appendix II") at day $3,5,8,14$, and 21 of ripening. Diameters were measured to correct the distance from the core/center according to the shrinkage of the sausages.

All formulations showed an U-shaped moisture versus diameter distribution profile meaning higher contents in the core compared to the outer layers (Fig. 2). Respective moisture gradients were increasing with increasing drying time from an average of $11.1 \%$ (3 d) to $20.6 \%$ (Hybrid 50), 21.5\% (Control, Hybrid 37.5), 22.1\% (Hybrid 12.5), and 22.3\% (Hybrid 25) after 21 days. Furthermore, varying moisture in raw (hybrid) meat batters (Table 3) resulted in differences among samples in the order of Hybrid $50<$ Hybrid $37.5<$ Hybrid $25<$ Hybrid $12.5<$ Control. For example, moisture levels after $3 \mathrm{~d}$ were $54.2 \pm 0.1 \%$ (Hybrid 50), 56.2 $\pm 0.1 \%$ (Hybrid 37.5), 56.6 $\pm 0.6 \%$ (Hybrid 25), 59.0 $\pm 0.1 \%$ (Hybrid 12.5), and $60.8 \pm 0.7$ (Control) in the Core Layer and $43.0 \pm 0.1 \%, 45.1 \pm 0.1 \%$, $46.2 \pm 0.1 \%, 47.6 \pm 0.1 \%$, and $49.5 \pm 0.1 \%$ in the outer Layer I, respectively ("Appendix I"). Differences among formulations were mostly significant $(p \leq 0.05)$ in Layer I, II, and III except for Hybrid 50 sausages where moisture levels were comparable or even significantly $(p \leq 0.05)$ higher than in the Hybrid 37.5 in the third drying regime. Moreover, a trend towards lowered differences among all formulations with ongoing ripening time could be deduced (Fig. 2). As such, moisture levels in Layer IV (core) of the Control and Hybrid 12.5 sausages were diverging over time, and values after 21 days were around $49 \%$ and $48 \%$, respectively. In contrast, Hybrid 25, 37.5, and 50 were similar starting from day 8 and showed no significant $(p>0.05)$ difference at day 14 and 21 ("Appendix I").

The time-dependent moisture changes of hybrids were thus in principal similar to those of dry-cured sausages with gradients developing during drying and equilibration of salt and water across the matrix [6, 41]. Fabbri and Cevoli [41] found that moisture distributions in raw meat batters (day 0 ) became gradual after 1 day of drying and a distinct gradient over four distinct zones along the diameter of sausages was reached after 28 days of ripening. Baldini et al. [9] observed that moisture levels of Mènage (50-55 mm diameter) were around $59 \%$ in both the external and the core fraction at day 0 and decreased by 12 and $4 \%$, respectively until day 7. Accordingly, dry-cured (hybrid) sausages $(50-55 \mathrm{~mm}$ diameter) had 10 to $13 \%$ of moisture loss in the outer Layer I and 2 to $3 \%$ in the core (Layer IV) after 8 days (Fig. 2). Baldini et al. [9] further showed that moisture levels among fractions differed not only depending on the variety, but also when different ripening parameters (temperature, relative humidity) were applied.

This underlines the importance of thorough process control to balance water diffusion on the inside and evaporation on the surface of the sausages. Otherwise, product defaults such as case hardening may occur, where sausages form a glassy barrier at the surface that may decelerate or even prevent drying yielding products with a high susceptibility towards microbial spoilage as well as a poor texture [6, 9]. Case hardening generally happens when the removal of water from the outside of the sausage is higher than the moisture migration from the inside [42]. It also affects phenomena such as product shrinkages and appearance of wrinkles or dents. As seen in Fig. 2, moisture levels of all formulations decreased steadily during drying, but shrinkage of the Hybrid 50 was distinctively lower at later stages of drying (see distance from center after 8, 14, and 21 days). This and observations from Fig. 1 may hint at some case hardening at high meat replacement levels possibly due to differences in glass transition temperatures.

While the moisture level describes the whole amount of water in the samples, the $\mathrm{a}_{\mathrm{w}}$-value is representative for the amount of free water and thus the amount that can be dried-off more easily. Figure 3 shows the $a_{\mathrm{w}}$ values of sausage Layer I-IV at day 3, 5, 8, 14, and 21, and illustrates that differences in the development of the spatial free water distribution profiles of the five formulations develop over 

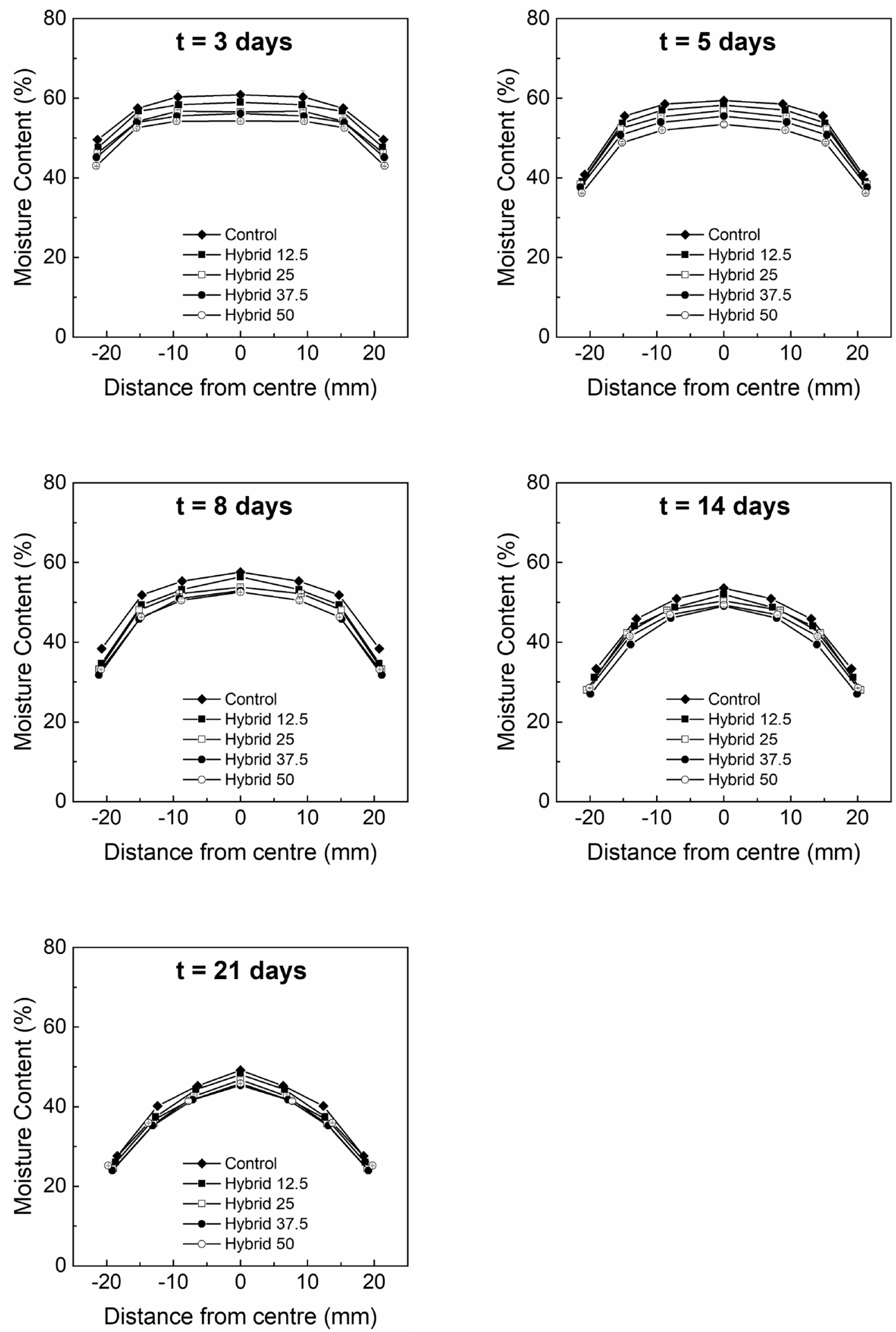

Fig. 2 Moisture content (\%) along the diameter of the control formulation and dry-cured hybrids during ripening after 3, 5, 8, 14, and 21 days (RH 94\% (1 day), 85\% (5 days), 80\% (5 days), 75\% (5 days), $72 \%$ (5 days)) 

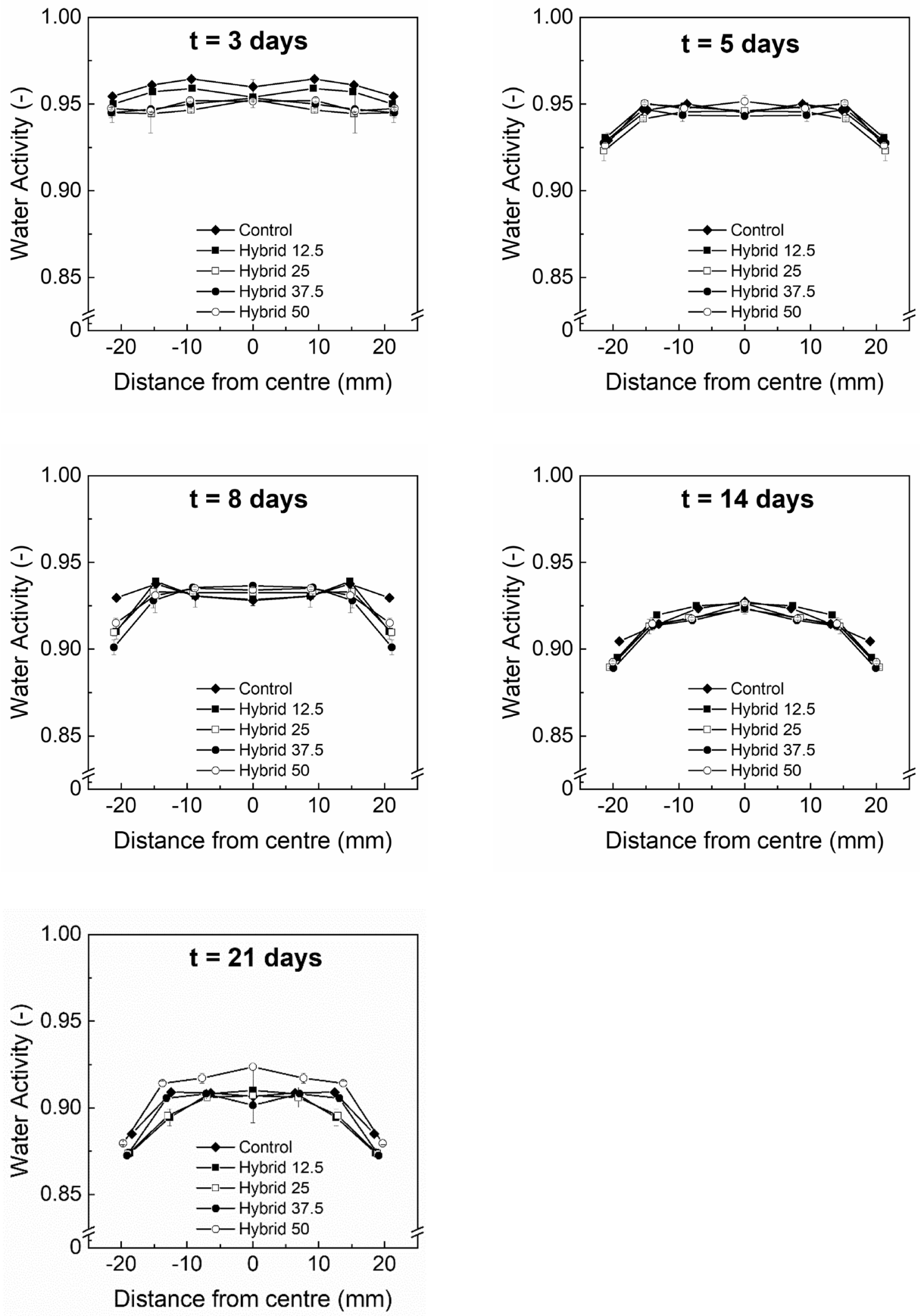

Fig. 3 Free water content $\left(a_{\mathrm{w}}\right)$ along the diameter of the control formulation and dry-cured hybrids during ripening after 3, 5, 8, 14, and 21 days (RH $94 \%$ ( 1 day), $85 \%$ (5 days), $80 \%$ (5 days), $75 \%$ (5 days), $72 \%$ (5 days)) 
time. These differences in final $a_{\mathrm{w}}$ values after 21 days increase in the order of Hybrid 12.5 Hybrid $25<$ Control $<$ Hybrid $37.5<<$ Hybrid 50. Food products often consist of hygroscopic, porous materials. In such systems, sorptively bound water limits the amount of water that can be removed, since they can only be dried until the so-called equilibrium moisture content is reached [30]. Micro- and macrosized capillaries and pores enable liquid and gas transport through the matrix e.g. by capillary motion, hydrodynamic and Knudsen flow, as well as liquid, vapor, and surface diffusion [43]. Differences in these structural features combined with differences in individual water holding capacity of compounds could be an explanation for the observed different drying behavior and end state of solely meat-based and hybrid samples. Cornet et al. [44] recently demonstrated that soy-gluten-based meat analogs possessed water-filled cavities that may enable an easy and fast release of water. They also discussed that the initial moisture release might be more intense than for meat, where the water holding capacity is highly dependent on the spatial organization and state of myofibrillar proteins [45]. While they looked primarily at the behavior of meat analogs under compression, the outlined findings could still explain the somewhat faster drying behavior of the Hybrid 12.5 and 25 compared to the Control (Fig. 1A). In addition, presence of dietary fibers in wet extrudates might not only lead to modulated water binding, but may also limit the release of water through the blockage of cavities in the matrix due to swelling [39]. Likely, a complex interplay of structural features and physicochemical properties is behind the observed differences that will require more detailed studies.

\section{Texture and appearance}

Key textural attributes of non-heat treated, dry-cured sausages are a good sliceability along with a coherent, elastic texture that evolves through a solidification of the coagulated meat-protein gel upon drying [25]. Moreover, color displays an important quality attribute that influences consumer acceptance of meat analogs. Therefore, dry-cured (hybrid) sausages were analyzed in color (CIE-lab) and subjected to texture profile analysis (double compression test) after 21 days of ripening (Table 4). The replacement of meat by increasing concentrations of pumpkin seed extrudates resulted in a higher lightness $L^{*}$ and all dry-cured hybrid sausages were significantly $(p \leq 0.05)$ less red $\left(a^{*}\right)$ and more yellow $\left(b^{*}\right)$ compared to the Control. This is also reflected in high color distances $\Delta E$ of $4.13 \pm 1.38$ (Hybrid 12.5), $8.21 \pm 1.80$ (Hybrid 25), 11.1 \pm 1.0 (Hybrid 37.5), and $13.7 \pm 1.3$ (Hybrid 50). When it comes to texture, hardness of the Control and Hybrid 12.5 and Hybrid 25 were not significantly $(p>0.05)$ different, but hybrid formulations deviated from the all-meat control in all other textural attributes. For example, cohesiveness decreased from $0.487 \pm 0.012$ (Control Formulation) to $0.408 \pm 0.013$ (Hybrid 12.5), $0.386 \pm 0.011$ (Hybrid 25), $0.336 \pm 0.008$ (Hybrid 37.5), and $0.256 \pm 0.005$ (Hybrid 50). Similarly, springiness was lower and declined from $4.88 \pm 0.16 \mathrm{~mm}$ (Control) to as little as $3.88 \pm 0.16 \mathrm{~mm}$ (Hybrid 50). Effects on the chewiness were similar at meat replacement levels of 12.5 and $25 \%$ with - $139 \mathrm{Nmm},-146 \mathrm{Nmm}$, but markedly higher for $37.5 \%$ with $-178 \mathrm{Nmm}$. Chewiness of Hybrid 50 was substantially lower than all other samples, with only $30 \%$ of the value of the Control.

Table 4 Appearance, color values, and parameters derived from texture profile analysis (deformation 50\%) of the control formulation and drycured hybrid sausages after 21 days of ripening

\begin{tabular}{|c|c|c|c|c|c|}
\hline Parameter & Control & Hybrid 12.5 & Hybrid 25 & Hybrid 37.5 & Hybrid 50 \\
\hline \multicolumn{6}{|l|}{ Appearance } \\
\hline Lightness $L^{*}(-)$ & $51.8 \pm 1.7^{\mathrm{c}}$ & $52.5 \pm 2.2^{\mathrm{c}}$ & $55.4 \pm 2.4^{\mathrm{b}}$ & $57.4 \pm 0.9^{\mathrm{a}}$ & $57.9 \pm 0.9^{\mathrm{a}}$ \\
\hline Red-Green balance $a^{*}(-)$ & $13.2 \pm 1.1^{\mathrm{a}}$ & $11.7 \pm 1.5^{\mathrm{b}}$ & $9.53 \pm 1.15^{\mathrm{c}}$ & $7.30 \pm 0.59^{\mathrm{d}}$ & $5.91 \pm 0.94^{\mathrm{e}}$ \\
\hline Yellow-blue balance $b^{*}(-)$ & $6.39 \pm 0.78^{\mathrm{e}}$ & $9.45 \pm 0.71^{\mathrm{d}}$ & $12.3 \pm 1.9^{\mathrm{c}}$ & $13.8 \pm 1.4^{\mathrm{b}}$ & $16.2 \pm 0.8^{\mathrm{a}}$ \\
\hline Color distance $\Delta E(-)$ & $0^{\mathrm{e}}$ & $4.13 \pm 1.38^{\mathrm{d}}$ & $8.21 \pm 1.80^{c}$ & $11.1 \pm 1.0^{\mathrm{b}}$ & $13.7 \pm 1.3^{\mathrm{a}}$ \\
\hline Cohesiveness (-) & $0.487 \pm 0.012^{\mathrm{a}}$ & $0.408 \pm 0.013^{\mathrm{b}}$ & $0.386 \pm 0.011^{\mathrm{c}}$ & $0.336 \pm 0.008^{\mathrm{d}}$ & $0.256 \pm 0.005^{\mathrm{e}}$ \\
\hline Springiness $(\mathrm{mm})$ & $4.88 \pm 0.16^{\mathrm{a}}$ & $4.56 \pm 0.18^{b}$ & $4.56 \pm 0.17^{b}$ & $4.28 \pm 0.24^{\mathrm{c}}$ & $3.88 \pm 0.16^{\mathrm{d}}$ \\
\hline Chewiness (Nmm) & $614 \pm 42^{a}$ & $475 \pm 38^{b}$ & $468 \pm 44^{\mathrm{bc}}$ & $436 \pm 37^{\mathrm{c}}$ & $180 \pm 12^{\mathrm{d}}$ \\
\hline
\end{tabular}

Different lower-case letters indicate significant difference $(p \leq 0.05)$ among formulations and the same textural parameter or color value 
It has already been shown that an incorporation of alternative proteins or fibers causes distinct color changes of meat products and most authors found decreasing $a^{*}$ and increasing $b^{*}$-values especially at high meat replacement levels $[31,32,36-38,40]$. The red color of meat products is based on the conversion of myoglobin to the red meat colorant nitrosomyoglobin after its reaction with nitrite, which is characteristic for meat products [6]. As such, decreasing contents of meat proteins lower the number of reactants to form nitrosomyoglobin allowing the light green color of pumpkin seed extrudates to exert an influence (Table 4). This influence could be correlated with the meat replacement level at 12.5 and $25 \%$ with $a^{*}$ decreasing by 11.4 and $27.8 \%$, but not at higher meat replacement levels hinting to a hindrance of the red color formation irrespective of sufficient amounts of nitrite curing salt in the formulation (Table 1). Moreover, lower amounts of meat protein resulted in a lowered capability to form gels upon acidification and drying [25], which accounts for changes in the textural parameters (Table 4), in particular at meat replacement levels of $>25 \%$. Results also fit to previously reported studies, e.g. texturized plant proteins were included into beef sausage [31] or goat meat patties [46], or meat in frankfurters was partly replaced by rice bran [47]. Kamani et al. [22] reported a lowered hardness, chewiness, cohesiveness, and springiness of boiled chicken sausage when meat was partly or fully replaced with a soy-gluten analog. Based on their findings Alvarez et al. [47] suggested an interference of non-meat ingredients on the heat-induced gelation of frankfurters, while Hidayat et al. [31] proposed an interplay of fat reduction and higher water contents through the replacement of meat with texturized plant proteins.

Figure 4 summarizes our findings on the effect of pumpkin extrudates in dry-cured hybrid sausages. It is suggested that $25 \%$ of meat replacement constitutes an important threshold above which distinct effects on the drying behavior, texture, and color of end products can be observed. This may be related to structural and compositional differences imparted by the extrudates that may lead to an altered water binding and migration behavior. There are still a lot of open questions as to the role of molecular interactions between alternative and meat proteins i.e. the role that in particular non-covalent interactions such as hydrophobic or electrostatic ones play, as it has been recently shown that the association of meat proteins is affected by a functional potato protein fraction $[48,49]$. Furthermore, it is not clear under what conditions extrudates act as active or purely passive (inert) fillers in the matrix - and depending on this-whether they represent defects in the meat gel matrix or provide additional mechanical strength to the matrix. Some extrudates contain still soluble proteins that may be capable of binding with meat proteins and/or altering their functionality, while others may not.

\section{Conclusion}

Analysis on the ripening behavior, color, and texture of dry-cured hybrid sausages and a traditional all-meat recipe provided valuable insights into the effect of adding texturized plant proteins as meat alternatives. A meat replacement
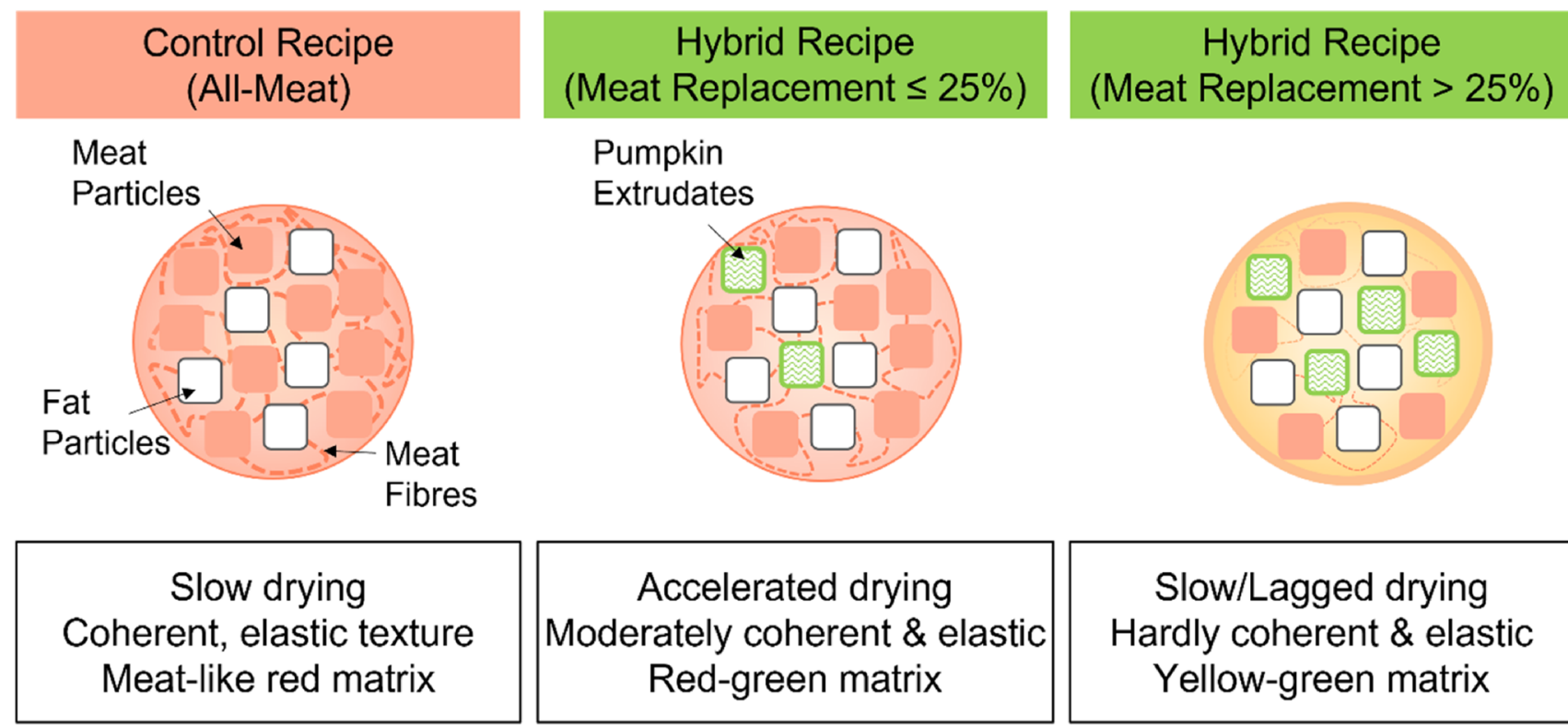

\section{Marticles}

\section{Pumpkin}

Accelerated drying

Red-green matrix

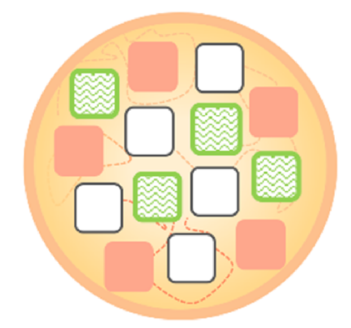

Fig. 4 Schematic overview of the effect of pumpkin extrudates on the drying behavior and properties of dry-cured hybrids 
that exceeded $25 \%$ altered the drying speed and distribution of moisture and increased the risk of case hardening and undesirable changes in color and texture. This was mostly related to differences in the proximate composition of formulations based on varying extrudates shares, which caused changes in water migration and binding and on the deviation of extrudates from the acid-induced texture formation of meat proteins. Thus, manufacturers of plant-based extrudates should not only aim to generate the macroscopic, fibrous properties of meat, but also play close attention to these physicochemical and functional properties. Nevertheless, the addition of suitable binders that can interact with both meat and/or extrudates might be of key importance to support cohesion and structural integrity in meat hybrids and analogs, which is a prerequisite to creating products with high consumer acceptability. Besides, meat replacers may cause favorable and/or unfavorable organoleptic changes. At the end, both these raw material specific and final product characteristics, as well as consumer-related aspects should be taken into account to broaden the commercial relevance of hybrid meat products.

\section{Appendix I}

Moisture content ( $\mathrm{g} / 100 \mathrm{~g}$ ) of whole sausage and along the diameter of the control formulation and dry-cured hybrids at 3, 5, 8, 14, and 21 days of ripening (RH 94\% (1 day), 85\% (5 days), $80 \%$ (5 days), $75 \%$ (5 days), $72 \%$ (5 days)).

\begin{tabular}{|c|c|c|c|c|c|c|}
\hline & $\begin{array}{l}\text { Time } \\
\text { (days) }\end{array}$ & Control & Hybrid 12.5 & Hybrid 25 & Hybrid 37.5 & Hybrid 50 \\
\hline \multirow[t]{5}{*}{ Layer 1} & 3 & $49.5 \pm 0.1^{\mathrm{a}, \mathrm{C}}$ & $47.6 \pm 0.1^{\mathrm{b}, \mathrm{D}}$ & $46.2 \pm 0.1^{\mathrm{c}, \mathrm{C}}$ & $45.1 \pm 0.1^{\mathrm{d}, \mathrm{D}}$ & $43.0 \pm 0.1^{\mathrm{e}, \mathrm{C}}$ \\
\hline & 5 & $40.8 \pm 0.4^{\mathrm{a}, \mathrm{C}}$ & $39.1 \pm 0.1^{\mathrm{b}, \mathrm{C}}$ & $38.4 \pm 0.1^{\mathrm{bc}, \mathrm{D}}$ & $37.6 \pm 0.7^{\mathrm{c}, \mathrm{D}}$ & $36.2 \pm 0.1^{\mathrm{d}, \mathrm{D}}$ \\
\hline & 8 & $38.3 \pm 0.2^{\mathrm{a}, \mathrm{D}}$ & $34.6 \pm 0.4^{\mathrm{b}, \mathrm{D}}$ & $33.2 \pm 0.2^{\mathrm{c}, \mathrm{D}}$ & $31.7 \pm 0.4^{\mathrm{d}, \mathrm{D}}$ & $33.1 \pm 0.1^{\mathrm{c}, \mathrm{D}}$ \\
\hline & 14 & $33.3 \pm 0.8^{\mathrm{a}, \mathrm{D}}$ & $31.1 \pm 0.2^{\mathrm{b}, \mathrm{D}}$ & $28.0 \pm 0.1^{\mathrm{c}, \mathrm{D}}$ & $27.0 \pm 0.1^{\mathrm{d}, \mathrm{D}}$ & $28.5 \pm 0.1^{\mathrm{c}, \mathrm{D}}$ \\
\hline & 21 & $27.6 \pm 0.5^{\mathrm{a}, \mathrm{D}}$ & $26.0 \pm 0.1^{\mathrm{b}, \mathrm{D}}$ & $24.4 \pm 0.4^{\mathrm{d}, \mathrm{D}}$ & $23.9 \pm 0.1^{\mathrm{d}, \mathrm{D}}$ & $25.2 \pm 0.1^{\mathrm{c}, \mathrm{D}}$ \\
\hline \multirow[t]{5}{*}{ Layer II } & 3 & $57.5 \pm 0.2^{\mathrm{a}, \mathrm{B}}$ & $56.7 \pm 0.1^{\mathrm{a}, \mathrm{C}}$ & $54.2 \pm 1.4^{\mathrm{b}, \mathrm{B}}$ & $53.9 \pm 0.1^{\mathrm{b}, \mathrm{C}}$ & $52.6 \pm 0.2^{\mathrm{b}, \mathrm{B}}$ \\
\hline & 5 & $55.6 \pm 0.5^{\mathrm{a}, \mathrm{B}}$ & $53.7 \pm 0.1^{\mathrm{b}, \mathrm{B}}$ & $52.4 \pm 0.6^{\mathrm{c}, \mathrm{C}}$ & $50.7 \pm 0.1^{\mathrm{d}, \mathrm{C}}$ & $48.8 \pm 0.3^{\mathrm{e}, \mathrm{C}}$ \\
\hline & 8 & $51.8 \pm 0.1^{\mathrm{a}, \mathrm{C}}$ & $49.3 \pm 0.3^{\mathrm{b}, \mathrm{C}}$ & $48.1 \pm 0.7^{\mathrm{c}, \mathrm{C}}$ & $45.8 \pm 0.1^{\mathrm{d}, \mathrm{C}}$ & $46.3 \pm 0.1^{\mathrm{d}, \mathrm{C}}$ \\
\hline & 14 & $45.9 \pm 0.3^{\mathrm{a}, \mathrm{C}}$ & $44.0 \pm 0.1^{\mathrm{b}, \mathrm{C}}$ & $42.3 \pm 0.4^{\mathrm{c}, \mathrm{C}}$ & $39.4 \pm 0.1^{\mathrm{e}, \mathrm{C}}$ & $41.4 \pm 0.2^{\mathrm{d}, \mathrm{C}}$ \\
\hline & 21 & $40.2 \pm 0.1^{\mathrm{a}, \mathrm{C}}$ & $37.5 \pm 0.3^{\mathrm{b}, \mathrm{C}}$ & $35.7 \pm 0.2^{\mathrm{cd}, \mathrm{C}}$ & $35.2 \pm 0.3^{\mathrm{d}, \mathrm{C}}$ & $35.9 \pm 0.2^{\mathrm{c}, \mathrm{C}}$ \\
\hline \multirow[t]{5}{*}{ Layer III } & 3 & $60.3 \pm 1.6^{\mathrm{a}, \mathrm{A}}$ & $58.3 \pm 0.1^{\mathrm{b}, \mathrm{B}}$ & $56.7 \pm 0.4^{\mathrm{bc}, \mathrm{A}}$ & $55.5 \pm 0.5^{\mathrm{cd}, \mathrm{B}}$ & $54.2 \pm 0.2^{\mathrm{d}, \mathrm{A}}$ \\
\hline & 5 & $58.6 \pm 0.1^{\mathrm{a}, \mathrm{A}}$ & $57.0 \pm 0.4^{\mathrm{b}, \mathrm{A}}$ & $55.3 \pm 0.3^{\mathrm{c}, \mathrm{B}}$ & $53.9 \pm 0.1^{\mathrm{d}, \mathrm{B}}$ & $52.0 \pm 0.1^{\mathrm{e}, \mathrm{B}}$ \\
\hline & 8 & $55.3 \pm 0.3^{\mathrm{a}, \mathrm{B}}$ & $53.2 \pm 0.2^{\mathrm{b}, \mathrm{B}}$ & $52.1 \pm 0.1^{\mathrm{c}, \mathrm{B}}$ & $51.0 \pm 0.2^{\mathrm{d}, \mathrm{B}}$ & $50.5 \pm 0.4^{\mathrm{d}, \mathrm{B}}$ \\
\hline & 14 & $50.9 \pm 0.2^{\mathrm{a}, \mathrm{B}}$ & $48.8 \pm 0.2^{\mathrm{b}, \mathrm{B}}$ & $48.0 \pm 0.3^{\mathrm{c}, \mathrm{B}}$ & $46.0 \pm 0.1^{\mathrm{e}, \mathrm{B}}$ & $46.8 \pm 0.1^{\mathrm{d}, \mathrm{B}}$ \\
\hline & 21 & $45.2 \pm 0.3^{\mathrm{a}, \mathrm{B}}$ & $44.3 \pm 0.4^{\mathrm{a}, \mathrm{B}}$ & $42.6 \pm 0.4^{\mathrm{b}, \mathrm{B}}$ & $41.7 \pm 0.2^{\mathrm{c}, \mathrm{B}}$ & $41.4 \pm 0.6^{\mathrm{c}, \mathrm{B}}$ \\
\hline \multirow[t]{5}{*}{ Core Layer } & 3 & $60.8 \pm 0.7^{\mathrm{a}, \mathrm{A}}$ & $59.0 \pm 0.1^{\mathrm{b}, \mathrm{A}}$ & $56.6 \pm 0.6^{\mathrm{c}, \mathrm{A}}$ & $56.2 \pm 0.1^{\mathrm{c}, \mathrm{A}}$ & $54.2 \pm 0.1^{\mathrm{d}, \mathrm{A}}$ \\
\hline & 5 & $59.4 \pm 0.2^{\mathrm{a}, \mathrm{A}}$ & $58.2 \pm 1.1^{\mathrm{ab}, \mathrm{A}}$ & $56.9 \pm 0.6^{\mathrm{bc}, \mathrm{A}}$ & $55.5 \pm 0.1^{\mathrm{c}, \mathrm{A}}$ & $53.4 \pm 0.5^{\mathrm{d}, \mathrm{A}}$ \\
\hline & 8 & $57.6 \pm 0.8^{\mathrm{a}, \mathrm{A}}$ & $56.4 \pm 0.1^{\mathrm{b}, \mathrm{A}}$ & $53.8 \pm 0.6^{\mathrm{c}, \mathrm{A}}$ & $52.9 \pm 0.1^{\mathrm{cd}, \mathrm{A}}$ & $52.6 \pm 0.1^{\mathrm{d}, \mathrm{A}}$ \\
\hline & 14 & $53.6 \pm 0.1^{\mathrm{a}, \mathrm{A}}$ & $51.9 \pm 0.3^{\mathrm{b}, \mathrm{A}}$ & $50.4 \pm 0.6^{\mathrm{c}, \mathrm{A}}$ & $49.1 \pm 0.4^{\mathrm{c}, \mathrm{A}}$ & $49.3 \pm 0.5^{\mathrm{c}, \mathrm{A}}$ \\
\hline & 21 & $49.1 \pm 0.5^{\mathrm{a}, \mathrm{A}}$ & $48.1 \pm 1.4^{\mathrm{ab}, \mathrm{A}}$ & $46.8 \pm 0.6^{\mathrm{bc}, \mathrm{A}}$ & $45.4 \pm 0.2^{\mathrm{c}, \mathrm{A}}$ & $45.8 \pm 0.1^{\mathrm{c}, \mathrm{A}}$ \\
\hline
\end{tabular}

Different lower-case letters indicate significant difference $(p \leq 0.05)$ among formulations in the same layer and timepoint

Different upper-case letters indicate significant difference $(p \leq 0.05)$ among layers from the same formulation and timepoint 


\section{Appendix II}

Water activity $a_{\mathrm{w}}(-)$ of whole sausage and along the diameter of the control formulation and dry-cured hybrids at 3 , $5,8,14$, and 21 days of ripening (RH 94\% (1 day), 85\% (5 days), $80 \%$ ( 5 days), $75 \%$ (5 days), $72 \%$ (5 days)).

\begin{tabular}{|c|c|c|c|c|c|c|}
\hline & $\begin{array}{l}\text { Time } \\
\text { (days) }\end{array}$ & Control & Hybrid 12.5 & Hybrid 25 & Hybrid 37.5 & Hybrid 50 \\
\hline \multirow[t]{5}{*}{ Layer 1} & 3 & $0.955 \pm 0.002^{\mathrm{a}, \mathrm{B}}$ & $0.950 \pm 0.001^{\mathrm{ab}, \mathrm{C}}$ & $0.945 \pm 0.006^{\mathrm{b}, \mathrm{A}}$ & $0.945 \pm 0.003^{\mathrm{b}, \mathrm{B}}$ & $0.948 \pm 0.001^{\mathrm{ab}, \mathrm{A}}$ \\
\hline & 5 & $0.929 \pm 0.004^{\mathrm{a}, \mathrm{B}}$ & $0.931 \pm 0.002^{\mathrm{a}, \mathrm{B}}$ & $0.923 \pm 0.006^{\mathrm{a}, \mathrm{B}}$ & $0.928 \pm 0.004^{\mathrm{a}, \mathrm{B}}$ & $0.926 \pm 0.001^{\mathrm{a}, \mathrm{B}}$ \\
\hline & 8 & $0.930 \pm 0.001^{\mathrm{a}, \mathrm{B}}$ & $0.910 \pm 0.004^{\mathrm{b}, \mathrm{B}}$ & $0.910 \pm 0.002^{\mathrm{b}, \mathrm{B}}$ & $0.901 \pm 0.004^{\mathrm{c}, \mathrm{C}}$ & $0.915 \pm 0.003^{\mathrm{b}, \mathrm{B}}$ \\
\hline & 14 & $0.905 \pm 0.001^{\mathrm{a}, \mathrm{C}}$ & $0.895 \pm 0.001^{\mathrm{b}, \mathrm{C}}$ & $0.890 \pm 0.001^{\mathrm{d}, \mathrm{C}}$ & $0.889 \pm 0.001^{\mathrm{d}, \mathrm{C}}$ & $0.893 \pm 0.001^{\mathrm{c}, \mathrm{C}}$ \\
\hline & 21 & $0.885 \pm 0.001^{\mathrm{a}, \mathrm{B}}$ & $0.874 \pm 0.003^{\mathrm{c}, \mathrm{C}}$ & $0.874 \pm 0.002^{\mathrm{c}, \mathrm{B}}$ & $0.873 \pm 0.001^{\mathrm{c}, \mathrm{C}}$ & $0.880 \pm 0.001^{\mathrm{b}, \mathrm{C}}$ \\
\hline \multirow[t]{5}{*}{ Layer II } & 3 & $0.961 \pm 0.001^{\mathrm{a}, \mathrm{AB}}$ & $0.957 \pm 0.001^{\mathrm{ab}, \mathrm{C}}$ & $0.945 \pm 0.001^{\mathrm{b}, \mathrm{A}}$ & $0.947 \pm 0.001^{\mathrm{ab}, \mathrm{B}}$ & $0.946 \pm 0.013^{\mathrm{ab}, \mathrm{A}}$ \\
\hline & 5 & $0.947 \pm 0.001^{\mathrm{b}, \mathrm{A}}$ & $0.950 \pm 0.001^{\mathrm{a}, \mathrm{A}}$ & $0.942 \pm 0.001^{\mathrm{c}, \mathrm{A}}$ & $0.947 \pm 0.001^{\mathrm{b}, \mathrm{A}}$ & $0.951 \pm 0.001^{\mathrm{a}, \mathrm{A}}$ \\
\hline & 8 & $0.938 \pm 0.002^{\mathrm{a}, \mathrm{A}}$ & $0.937 \pm 0.001^{\mathrm{a}, \mathrm{A}}$ & $0.933 \pm 0.004^{\mathrm{a}, \mathrm{A}}$ & $0.928 \pm 0.004^{\mathrm{a}, \mathrm{B}}$ & $0.931 \pm 0.010^{\mathrm{a}, \mathrm{A}}$ \\
\hline & 14 & $0.915 \pm 0.002^{\mathrm{a}, \mathrm{B}}$ & $0.920 \pm 0.001^{\mathrm{a}, \mathrm{B}}$ & $0.913 \pm 0.004^{\mathrm{a}, \mathrm{B}}$ & $0.914 \pm 0.002^{\mathrm{a}, \mathrm{B}}$ & $0.915 \pm 0.004^{\mathrm{a}, \mathrm{B}}$ \\
\hline & 21 & $0.909 \pm 0.001^{\mathrm{ab}, \mathrm{A}}$ & $0.895 \pm 0.005^{\mathrm{c}, \mathrm{B}}$ & $0.896 \pm 0.002^{\mathrm{c}, \mathrm{B}}$ & $0.906 \pm 0.001^{\mathrm{b}, \mathrm{AB}}$ & $0.914 \pm 0.001^{\mathrm{a}, \mathrm{B}}$ \\
\hline \multirow[t]{5}{*}{ Layer III } & 3 & $0.965 \pm 0.001^{\mathrm{a}, \mathrm{A}}$ & $0.959 \pm 0.001^{\mathrm{a}, \mathrm{B}}$ & $0.947 \pm 0.001^{\mathrm{b}, \mathrm{A}}$ & $0.950 \pm 0.001^{\mathrm{b}, \mathrm{AB}}$ & $0.952 \pm 0.001^{\mathrm{b}, \mathrm{A}}$ \\
\hline & 5 & $0.950 \pm 0.001^{\mathrm{a}, \mathrm{A}}$ & $0.949 \pm 0.002^{\mathrm{ab}, \mathrm{A}}$ & $0.946 \pm 0.002^{\mathrm{ab}, \mathrm{A}}$ & $0.944 \pm 0.004^{\mathrm{b}, \mathrm{A}}$ & $0.948 \pm 0.004^{\mathrm{ab}, \mathrm{A}}$ \\
\hline & 8 & $0.931 \pm 0.001^{\mathrm{a}, \mathrm{B}}$ & $0.931 \pm 0.006^{\mathrm{a}, \mathrm{A}}$ & $0.933 \pm 0.001^{\mathrm{a}, \mathrm{A}}$ & $0.936 \pm 0.001^{\mathrm{a}, \mathrm{A}}$ & $0.935 \pm 0.001^{\mathrm{a}, \mathrm{A}}$ \\
\hline & 14 & $0.924 \pm 0.002^{\mathrm{a}, \mathrm{A}}$ & $0.925 \pm 0.001^{\mathrm{a}, \mathrm{A}}$ & $0.918 \pm 0.001^{\mathrm{b}, \mathrm{AB}}$ & $0.917 \pm 0.001^{\mathrm{b}, \mathrm{B}}$ & $0.918 \pm 0.001^{\mathrm{b}, \mathrm{B}}$ \\
\hline & 21 & $0.909 \pm 0.001^{\mathrm{b}, \mathrm{A}}$ & $0.908 \pm 0.001^{\mathrm{b}, \mathrm{A}}$ & $0.906 \pm 0.006^{\mathrm{b}, \mathrm{A}}$ & $0.908 \pm 0.003^{\mathrm{b}, \mathrm{A}}$ & $0.917 \pm 0.003^{\mathrm{a}, \mathrm{B}}$ \\
\hline \multirow{5}{*}{$\begin{array}{l}\text { Core } \\
\text { Layer }\end{array}$} & 3 & $0.960 \pm 0.004^{\mathrm{a}, \mathrm{AB}}$ & $0.954 \pm 0.001^{\mathrm{ab}, \mathrm{A}}$ & $0.953 \pm 0.001^{\mathrm{b}, \mathrm{A}}$ & $0.954 \pm 0.002^{\mathrm{ab} \mathrm{A}}$ & $0.952 \pm 0.004^{\mathrm{b}, \mathrm{A}}$ \\
\hline & 5 & $0.945 \pm 0.003^{\mathrm{ab}, \mathrm{A}}$ & $0.946 \pm 0.001^{\mathrm{ab}, \mathrm{A}}$ & $0.946 \pm 0.004^{\mathrm{ab}, \mathrm{A}}$ & $0.943 \pm 0.001^{\mathrm{b}, \mathrm{A}}$ & $0.952 \pm 0.004^{\mathrm{a}, \mathrm{A}}$ \\
\hline & 8 & $0.928 \pm 0.003^{\mathrm{b}, \mathrm{B}}$ & $0.929 \pm 0.004^{\mathrm{b}, \mathrm{A}}$ & $0.933 \pm 0.002^{\mathrm{ab}, \mathrm{A}}$ & $0.937 \pm 0.001^{\mathrm{a}, \mathrm{B}}$ & $0.934 \pm 0.001^{\mathrm{ab}, \mathrm{A}}$ \\
\hline & 14 & $0.928 \pm 0.001^{\mathrm{a}, \mathrm{A}}$ & $0.927 \pm 0.001^{\mathrm{ab}, \mathrm{A}}$ & $0.923 \pm 0.003^{\mathrm{b}, \mathrm{A}}$ & $0.924 \pm 0.001^{\mathrm{b}, \mathrm{A}}$ & $0.927 \pm 0.001^{\mathrm{ab}, \mathrm{A}}$ \\
\hline & 21 & $0.907 \pm 0.004^{\mathrm{ab}, \mathrm{A}}$ & $0.910 \pm 0.001^{\mathrm{ab}, \mathrm{A}}$ & $0.907 \pm 0.016^{\mathrm{b}, \mathrm{A}}$ & $0.902 \pm 0.001^{\mathrm{b}, \mathrm{B}}$ & $0.924 \pm 0.002^{\mathrm{a}, \mathrm{A}}$ \\
\hline
\end{tabular}

Different lower-case letters indicate significant difference $(p \leq 0.05)$ among formulations in the same layer and timepoint

Different upper-case letters indicate significant difference $(p \leq 0.05)$ among layers from the same formulation and timepoint

Acknowledgements This work was supported by the AiF (German Federation of Industrial Research Associations) as part of the CORNET project "Meat Hybrid" (AiF 196EN) and funded as part of the Industrial Collective Research (IGF) program of the German Ministry of Economics and Energy (BMWi), based on a resolution of the German Parliament.

Funding Open Access funding enabled and organized by Projekt DEAL.

\section{Declarations}

Conflict of interest The authors declare that they have no known competing financial interests or personal relationships that could have appeared to influence the work reported in this paper.
Compliance with ethics requirements This article does not contain any studies with human participants or animals performed by any of the authors.

Open Access This article is licensed under a Creative Commons Attribution 4.0 International License, which permits use, sharing, adaptation, distribution and reproduction in any medium or format, as long as you give appropriate credit to the original author(s) and the source, provide a link to the Creative Commons licence, and indicate if changes were made. The images or other third party material in this article are included in the article's Creative Commons licence, unless indicated otherwise in a credit line to the material. If material is not included in the article's Creative Commons licence and your intended use is not permitted by statutory regulation or exceeds the permitted use, you will need to obtain permission directly from the copyright holder. To view a copy of this licence, visit http://creativecommons.org/licenses/by/4.0/. 


\section{References}

1. IFPRI (2017) Global Food Policy Report, 2017, Washington, DC: International Food Policy Research Institute (IFPRI), p 148

2. Godfray HCJ et al (2018) Meat consumption, health, and the environment. Science 361:6399. https://doi.org/10.1126/science. aam5324

3. Key TJ et al (2019) Consumption of meat, fish, dairy products, and eggs and risk of ischemic heart disease: a prospective study of 7198 incident cases among 409885 participants in the PanEuropean EPIC Cohort. Circulation 139(25):2835-2845. https:// doi.org/10.1161/CIRCULATIONAHA.118.038813

4. Osen R, Schweiggert-Weisz U (2016) High-moisture extrusion: meat analogues. Ref Module Food Sci 2016:1-7. https://doi.org/ 10.1016/B978-0-08-100596-5.03099-7

5. Elzerman JE, Van Boekel MA, Luning PA (2013) Exploring meat substitutes: consumer experiences and contextual factors. Br Food J. https://doi.org/10.1108/00070701311331490

6. Feiner G (2016) Salami: practical science and processing technology. Academic Press, Hoboken

7. McNeil JM (2019) The evaluation of pathogen survival in dry cured charcuterie style sausages, in Animal and Food Sciences. In: University of Kentucky: Kentucky, p 108

8. Colomer Sellas M et al (2021) Effect of pork back-fat reduction and substitution with texturized pea protein on acceptability and sensory characteristics of dry fermented sausages. CyTA-J Food 19(1):429-439. https://doi.org/10.1080/19476337.2021.1912188

9. Baldini $\mathrm{P}$ et al (2000) Dry sausages ripening: influence of thermohygrometric conditions on microbiological, chemical and physicochemical characteristics. Food Res Int 33(3):161-170. https://doi. org/10.1016/S0963-9969(00)00030-2

10. BVL (2005) Amtliche Sammlung von Untersuchungsverfahren nach § 64 LFGB, § 38 TabakerzG, § 28b GenTG, B.f.V.u. Lebensmittelsicherheit, Editor, Beuth

11. Barbut S (2014) Texture. In: Toldrá F et al (ed) handbook of fermented meat and poultry, pp 207-215

12. Li A et al (2021) Gelation mechanism and physical properties of glucono- $\delta$-lactone induced alginate sodium/casein composite gels. Food Hydrocolloids 118:106775. https://doi.org/10.1016/j.foodh yd.2021.106775

13. Herz EM et al (2021) Influence of transglutaminase on glucono$\delta$-lactone-induced soy protein gels. ACS Food Sci Technol 1(8):1412-1417. https://doi.org/10.1021/acsfoodscitech.1c00102

14. Sun C, Gao Y, Zhong Q (2018) Effects of acidification by gluconodelta-lactone or hydrochloric acid on structures of zein-caseinate nanocomplexes self-assembled during a $\mathrm{pH}$ cycle. Food Hydrocolloids 82:173-185. https://doi.org/10.1016/j.foodhyd.2018.04.007

15. Ngapo TM, Wilkinson BHP, Chong R (1996) 1,5-glucono- $\delta$ lactone-induced gelation of myofibrillar protein at chilled temperatures. Meat Sci 42(1):3-13. https://doi.org/10.1016/03091740(95)00028-3

16. Shimahara K, Takahashi T (1970) An infrared spectrophotometric study on the interconversion and hydrolysis of d-glucono- $\gamma$ - and $-\delta$-lactone in deuterium oxide. Biochim Biophys Acta (BBA) Gener Subj 201(3):410-415. https://doi.org/10.1016/03044165(70)90159-5

17. Van Krieken J, Bontenbal E (2013) Controlled acidification of food products using lactic-or glycolic acid oligomers/derivatives. 2013, Google Patents

18. Totosaus A, Gault NFS, Guerrero I (2000) Dynamic rheological behavior of meat proteins during acid-induced gelation. Int J Food Prop 3(3):465-472. https://doi.org/10.1080/10942910009524650
19. Porcella M et al (2001) Soy protein isolate added to vacuumpackaged chorizos: Effect on drip loss, quality characteristics and stability during refrigerated storage. Meat Sci 57(4):437-443. https://doi.org/10.1016/S0309-1740(00)00122-4

20. Mokni Ghribi A et al (2018) Toward the enhancement of sensory profile of sausage "Merguez" with chickpea protein concentrate. Meat Sci 143:74-80. https://doi.org/10.1016/j.meatsci.2018.04. 025

21. Zepeda Bastida A et al (2018) Sensory analysis and texture profile of chorizo using blends of rabbit meat and textured soybean protein. Nova Sci 10(21):391-402. https://doi.org/10.21640/ns. v10i21.1601

22. Kamani MH et al (2019) Partial and total replacement of meat by plant-based proteins in chicken sausage: evaluation of mechanical, physico-chemical and sensory characteristics. J Food Sci Technol 56(5):2660-2669. https://doi.org/10.1007/s13197-019-03754-1

23. Kilic B et al (2010) Effect of textured soy protein on quality characteristics of low fat cooked Kofte (Turkish meatball). J Anim Vet Adv 9(24):3048-3054. https://doi.org/10.3923/javaa.2010.3048. 3054

24. Grau R, Andres A, Barat JM (2014) Principles of drying, in handbook of fermented meat and poultry, p 31-38

25. Toldrá F, Flores M (2014) Sausages, types ofldry and semidry. In: Dikeman M, Devine C (eds) Encyclopedia of meat sciences (second edition). Academic Press, Oxford, pp 248-255

26. Rahman M, Perera C (2007) Handbook of food preservation, 2nd edn. CRC Press, Boca Raton

27. Walz FH et al (2017) Chemical and optical characterization of white efflorescences on dry fermented sausages under modified atmosphere packaging. J Sci Food Agric 97(14):4872-4879. https://doi.org/10.1002/jsfa.8358

28. Yim D-G, Jang K-H, Chung K-Y (2015) Effect of GdL addition on physico-chemical properties of fermented sausages during ripening. Korean J Food Sci Anim Resour 35(3):322-329. https://doi. org/10.5851/kosfa.2015.35.3.322

29. Walz FH et al (2018) Influence of different drying rates on mass transport of efflorescence-causing substances in thin caliber salamis during refrigerated storage in N2/CO2 MAP. Eur Food Res Technol 244(4):663-674. https://doi.org/10.1007/ s00217-017-2985-0

30. Krischer O, Kast W (1978) Trocknungstechnik: die wissenschaftlichen Grundlagen der Trocknungstechnik, 3 ed, vol 1. Springer, Berlin, Heidelberg, p 509

31. Hidayat B, Wea A, Andriati N (2018) Physicochemical, sensory attributes and protein profile by SDS-PAGE of beef sausage substituted with texturized vegetable proteins. Food Res 2(1):20-31. https://doi.org/10.26656/fr.2017.2(1).106

32. Deliza R et al (2002) The effects of colored textured soybean protein (TSP) on sensory and physical attributes of ground beef patties. J Sens Stud 17(2):121-132. https://doi.org/10.1111/j. 1745-459X.2002.tb00337.x

33. Rao L, Draughon F, Melton C (1984) Sensory characters of thuringer sausage extended with textured soy protein. J Food Sci 49(2):334-336. https://doi.org/10.1111/j.1365-2621.1984.tb124 15.x

34. Weiss $\mathbf{J}$ et al (2010) Advances in ingredient and processing systems for meat and meat products. Meat Sci 86(1):196-213. https:// doi.org/10.1016/j.meatsci.2010.05.008

35. Omwamba M, Mahungu SM, Faraj AK (2014) Effect of texturized soy protein on quality characteristics of beef samosas. Int J Food Stud 3:1. https://doi.org/10.7455/ijfs/3.1.2014.a7

36. Sánchez-Zapata E et al (2013) Evaluation of the effect of tiger nut fibre as a carrier of unsaturated fatty acids rich oil on the quality 
of dry-cured sausages. Food Bioprocess Technol 6(5):1181-1190. https://doi.org/10.1007/s11947-011-0733-1

37. Sayas-Barberá E et al (2012) Combined use of a probiotic culture and citrus fiber in a traditional sausage 'Longaniza de Pascua.' Food Control 27(2):343-350. https://doi.org/10.1016/j.foodcont. 2012.04.009

38. Yalınkılıç B, Kaban G, Kaya M (2012) The effects of different levels of orange fiber and fat on microbiological, physical, chemical and sensorial properties of sucuk. Food Microbiol 29(2):255-259. https://doi.org/10.1016/j.fm.2011.07.013

39. Chaplin MF (2003) Fibre and water binding. Proc Nutr Soc 62(1):223-227. https://doi.org/10.1079/PNS2002203

40. Fernández-López J et al (2007) Orange fibre as potential functional ingredient for dry-cured sausages. Eur Food Res Technol 226(1):1-6. https://doi.org/10.1007/s00217-006-0501-z

41. Fabbri A, Cevoli C (2015) 2D water transfer finite elements model of salami drying, based on real slice image and simplified geometry. J Food Eng 158:73-79. https://doi.org/10.1016/j.jfoodeng. 2015.03.005

42. Gulati T, Datta AK (2015) Mechanistic understanding of casehardening and texture development during drying of food materials. J Food Eng 166:119-138. https://doi.org/10.1016/j.jfoodeng. 2015.05.031

43. Trujillo FJ, Wiangkaew C, Pham QT (2007) Drying modeling and water diffusivity in beef meat. J Food Eng 78(1):74-85. https:// doi.org/10.1016/j.jfoodeng.2005.09.010

44. Cornet SHV et al (2020) Water release kinetics from soy protein gels and meat analogues as studied with confined compression. Innov Food Sci Emerg Technol 66:102528. https://doi.org/10. 1016/j.ifset.2020.102528
45. Bertram HC, Purslow PP, Andersen HJ (2002) Relationship between meat structure, water mobility, and distribution: a lowfield nuclear magnetic resonance study. J Agric Food Chem 50(4):824-829. https://doi.org/10.1021/jf010738f

46. Gujral HS et al (2002) Effect of liquid whole egg, fat and textured soy protein on the textural and cooking properties of raw and baked patties from goat meat. J Food Eng 53(4):377-385. https:// doi.org/10.1016/S0260-8774(01)00180-7

47. Álvarez D et al (2012) Textural and viscoelastic properties of pork frankfurters containing canola-olive oils, rice bran, and walnut. Meat Sci 92(1):8-15. https://doi.org/10.1016/j.meatsci.2012.03. 012

48. Ebert $\mathrm{S}$ et al (2021) Aggregation behavior of solubilized meatpotato protein mixtures. Food Hydrocolloids 113:106388. https:// doi.org/10.1016/j.foodhyd.2020.106388

49. Ebert $\mathrm{S}$ et al (2021) Establishing the mixing and solubilization behavior of pork meat and potato proteins at acidic to neutral $\mathrm{pH}$. ACS Food Sci Technol 1(3):410-417. https://doi.org/10.1021/ acsfoodscitech.0c00032

50. Mariotti F, Tomé D, Mirand PP (2008) Converting nitrogen into protein-beyond 625 and Jones' factors. Crit Rev Food Sci Nutr 48(2):177-184. https://doi.org/10.1080/10408390701279749

51. Milovanović MM et al (2014) Evaluation of the nutritional quality of wheat bread prepared with quinoa, buckwheat and pumpkin seed blends. J Agric Sci 59(3):318-328. https://doi.org/10.2298/ JAS1403319M

Publisher's Note Springer Nature remains neutral with regard to jurisdictional claims in published maps and institutional affiliations. 